$12-2011$

\title{
Do investors see through mistakes in reported earnings?
}

\author{
Katsiaryna Salavei Bardos \\ Fairfield University, kbardos@fairfield.edu \\ Joseph H. Golec \\ University of Connecticut \\ John P. Harding \\ University of Connecticut
}

Follow this and additional works at: https://digitalcommons.fairfield.edu/business-facultypubs Copyright (c) Michael G. Foster School of Business, University of Washington 2011. Publisher's version is available at:

http://journals.cambridge.org/action/displayJournal?jid=JFQ

\section{Peer Reviewed}

\section{Repository Citation}

Salavei Bardos, Katsiaryna; Golec, Joseph H.; and Harding, John P., "Do investors see through mistakes in reported earnings?" (2011). Business Faculty Publications. 25.

https://digitalcommons.fairfield.edu/business-facultypubs/25

\section{Published Citation}

Bardos, Katsiaryna Salavei, Joseph H. Golec, and John P. Harding. Dec. 2011. Do investors see through mistakes in reported earnings? Journal of Financial and Quantitative Analysis, 46 (6) p. 1917-1946

This item has been accepted for inclusion in DigitalCommons@Fairfield by an authorized administrator of DigitalCommons@Fairfield. It is brought to you by DigitalCommons@Fairfield with permission from the rightsholder(s) and is protected by copyright and/or related rights. You are free to use this item in any way that is permitted by the copyright and related rights legislation that applies to your use. For other uses, you need to obtain permission from the rights-holder(s) directly, unless additional rights are indicated by a Creative Commons license in the record and/or on the work itself. For more information, please contact digitalcommons@fairfield.edu. 


\title{
Do Investors See through Mistakes in Reported Earnings?
}

\author{
Katsiaryna Salavei Bardos, Joseph Golec, and John P. Harding*
}

\begin{abstract}
This study investigates whether investors see through materially misstated earnings, and whether they anticipate earnings restatements. For firms that restate at least one annual report, we find that investors are misled by mistakes in reported earnings at the time of initial earnings announcements. Investors react positively to the component of the favorable earnings surprise that will subsequently be restated, and they attach the same valuation to it as to the true earnings surprise. We also find that investors anticipate the subsequent downward restatements and start marking stock prices down several months before a restatement announcement, so that the full impact of a restatement is about three times as large as the restatement announcement effect. Indeed, we show that investors punish restating firms because the stock price gains that shareholders enjoy when firms initially announce overstated earnings are more than reversed by the time of the restatement announcement.
\end{abstract}

\section{Introduction}

Recent corporate scandals involving overstated earnings have motivated several Securities and Exchange Commission (SEC) rules and Sarbanes-Oxley Act of 2002 provisions aimed at boosting the integrity of financial reports (Palmrose, Richardson, and Scholz (2004)). The premise of these rules is that investors typically do not see through the standard financial reporting to identify accounting mistakes and earnings manipulations. But if investors use other private and public information to validate reported earnings, several of the new rules may be costly and unnecessary.

\footnotetext{
*Bardos, kbardos@ fairfield.edu, Dolan School of Business, Fairfield University, 1073 N. Benson Rd., Fairfield, CT 06824; and Golec, joseph.golec@business.uconn.edu, and Harding, john.harding@business.uconn.edu, School of Business, University of Connecticut, 2100 Hillside Rd., Unit 1041, Storrs, CT 06269. We are grateful to Paul Malatesta (the editor) and an anonymous referee for comments that substantially improved the paper. We thank Brandon Cline, Assaf Eisdorfer, Robert Faff, Carmelo Giaccotto, Neeraj Gupta, James Hilliard, Kose John, Andy (Young Han) Kim, Stanley Veliotis, Michael Willenborg, Nataliya Zaiats, and seminar participants at the Securities and Exchange Commission, the 19th Financial Management Association (FMA) Corporate Roundtable, the 2009 European Financial Management Association, the 2008 Eastern Finance Association, and the 2006 FMA doctoral student seminar. We are grateful to Reilly White, Alain Krapl, and especially Svitlana Pedorych for their research assistance. Earlier versions of the paper circulated under the title "Do Investors See through Mistakes in Financial Statements? Long-Run Evidence from Restatements."
} 
Surprisingly, earlier studies spend little time examining whether investors are fooled by erroneous financial statements. Instead, most focus on the value effects and stock trading behavior just before and after restatement announcements. ${ }^{1}$ But how often and for how long are investors misled? The importance of accurate and transparent financial statements in monitoring the health of large firms is center stage as the country assesses the causes of the 2008 financial crisis and plans regulatory reforms to prevent future crises. For example, accounting irregularities, such as those that went unnoticed by auditors and regulators prior to Lehman's demise, drew greater attention to the question of how much investors are misled by erroneous financial information (De la Merced (2010)).

The goal of this paper is to provide a comprehensive analysis of investors' ability to see through mistakes in financial statements. Our study differs from prior literature on restatements in that it focuses on market reaction to the original announcement of misstated earnings and the valuation of restating firms in the error period, which extends from the 1 st misstated period to the day of restatement announcement. ${ }^{2}$ To the best of our knowledge, no prior study examines the market reaction to initial announcements of incorrect earnings that are subsequently restated. Only one previous study examines valuation in the error period for an older and smaller sample of restatements (Kinney and McDaniel (1989)).

In the absence of mistakes in financial statements, abnormal returns associated with earnings announcements are an increasing function of earnings surprises. For our sample of 492 restatements, we decompose the earnings surprise into 2 components: the true earnings surprise and the surprise due to the error. ${ }^{3}$ If investors are misled by erroneous earnings and treat the correct and error components the same, then any associated abnormal returns will be proportionately the same for each component.

Indeed, for the subsample of firms that restated at least one annual report, we find that, during the error period, investors react positively to the error component of the earnings surprise and attach the same valuation to the error component of the earnings surprise as to the true part of the earnings surprise. Furthermore, our evidence suggests that investors are more misled by mistakes made at the beginning rather than at the end of the error period.

\footnotetext{
${ }^{1}$ Several studies document negative abnormal reaction to the announcement of restatements of about 9\% around a 2-day restatement announcement period (Palmrose et al. (2004), Agrawal and Cooper (2007), and Bardos, Golec, and Harding (2011)).

${ }^{2}$ For example, the error period of a company with a fiscal year-end on December 31 that restated 1999 and 2000 annual reports on April 10, 2001, starts on January 1, 1999, and ends on April 9, 2001.

${ }^{3}$ Mistakes in financial statements can be either intentional or unintentional. Some mistakes in financial statements can be due to pure internal control failure or judgment error, while the management of some firms can intentionally mislead investors. Richardson, Tuna, and Wu (2003) say that "it is reasonable to assume that earnings restatement firms can be characterized as firms who knowingly and intentionally engaged in earnings manipulation." We do not make a judgment regarding the intent of the company that makes a mistake and do not differentiate between intentional and unintentional mistakes in this study. Our focus is on the impact of mistakes on stock returns irrespective of the intent. We do differentiate between firms that acknowledged fraud during the announcement of the restatement. However, the identification of fraud is very difficult, because motivations for fraud and aggressive accounting are the same (DeFond and Jiambalvo (1991), Dechow and Skinner (2000)). Moreover, the acknowledgment of fraud as a reason for restatement can be due to embezzlement by lower rank employees rather than the misdeeds of top level management.
} 
Firms that restate earnings downward experience negative abnormal returns several months before they restate. This result holds for both annual and quarterly restatements (restate only 10-Qs) and for various methods of calculating abnormal returns. The magnitude of abnormal buy-and-hold returns prior to restatement announcements is more than twice the announcement effect. ${ }^{4}$ Indeed, these negative abnormal returns more than offset the initial positive abnormal returns enjoyed by firms when they initially report overstated earnings. Furthermore, firms with downward quarterly restatements exhibit negative abnormal performance after the restatement announcement. Hence, the total negative impact of a restatement is much larger than the announcement effect. Overall our findings indicate that the market punishes restating firms with a discount that is greater than the misvaluation created by the misstated earnings.

Somewhat surprisingly, we find that firms that understate earnings and thus subsequently restate earnings upward also experience negative abnormal returns 1 month prior to their restatement and at the restatement announcement, suggesting that restatements are bad news even when firms revise earnings upward.

Securities regulators could interpret our results as supporting the view that investors would benefit from improved financial reporting practices. Although investors start to anticipate restatements several months prior to announcement, they are misled at the initial announcement of erroneous earnings. The average length of the error period is 2 years for the full sample and 2.5 years for annual restatements, so investors trade on erroneous information for quite some time.

In addition to examining valuation in the error period, we also study returns of restating firms during 2 other periods: i) the 3 -year period prior to the 1 st restated report (pre-error period); ii) and the 3-year period after the restatement announcement (post-restatement period). We find little evidence of abnormal performance in the pre-error period and find some evidence of negative abnormal performance in the post-restatement period for firms that restate net income downward. Furthermore, we find that firms that make mistakes in core accounts, such as revenue and cost, underperform more than other restating firms in the last quartile of the error period, suggesting that investors penalize firms more for core account mistakes. ${ }^{5}$ Firms that commit fraud and later restate have better performance in the 1st quartile of the error period than nonfraud restaters, suggesting that fraudulent earnings misstatements are harder to detect.

Our paper contributes to the literature that studies penalties for firms that misreport earnings. Several papers find that the costs of equity and debt are adversely affected by a restatement. Kravet and Shevlin (2010) find that restatements increase information risk, which results in higher opportunity cost of equity capital. Similarly, Hribar and Jenkins (2004) show that the implied cost of equity goes up after restatement. Graham, Li, and Qiu (2008) show that the cost of debt is also adversely affected by restatement announcement. Chen, Cheng, and Lo (2009) find that restating firms become financially constrained and are less likely to obtain external financing after restatements. Wilson (2008) finds that the information

\footnotetext{
${ }^{4}$ Announcement effect calculated for a 3-day window around restatement starting on day -1 equals $-11 \%(-10 \%)$ for annual (quarterly) downward restatements.

${ }^{5}$ Quartile of the error period is equal to $1 / 4$ of the error period and is firm specific.
} 
content of earnings temporarily declines following a restatement. Moreover, restating firms decrease labor and investment after restatement (Kedia and Philippon (2009)). Finally, Karpoff, Lee, and Martin (2008) find evidence of high legal and reputation costs for firms charged by the SEC with financial misrepresentation, many of which restate financial statements.

The rest of the paper proceeds as follows. Section II contains a restatement time line, research questions, and statistical methods. Section III describes the data. Section IV reports test results and their implications. Section V concludes the paper.

\section{Restatement Time Line, Research Questions, and Methods}

\section{A. Restatement Time Line and Return Periods Defined}

Several prior studies provided partial evidence regarding firm valuation in different parts of the error period. We define the error period as the time between the start of the 1st restated reporting period and the restatement announcement. No prior study, with the exception of Kinney and McDaniel (1989), carefully defines the error period or analyzes returns during that time. Most previous studies use fixed time windows around the restatement or the beginning of the error period and consequently mix returns from the pre-error, error, and post-restatement periods. ${ }^{6}$ Kinney and McDaniel examine the error period and find negative abnormal returns (measured for the full error period) for a limited sample (73 quarterly restatements filed between 1976 and 1985). But they do not break the error period into subperiods, and unlike other studies, for their limited sample, they do not find significant negative abnormal returns at the restatement announcement, suggesting that the sample may not be representative of more recent restatements.

Figure 1 illustrates the restatement time line. We start by precisely defining the error period $\left(D_{0}^{\mathrm{MISTAKE}}, D_{0}^{\mathrm{RESTATEMENT}}\right)$. It begins at the start of the $1 \mathrm{st}$ reporting period that contains a mistake in earnings $\left(D_{0}^{\text {MISTAKE }}\right)$ and ends on day $D_{0}^{\text {RESTATEMENT }}$, when management corrects earnings and reveals their true value. ${ }^{7}$

Finance theory suggests that investors value stock using expected future cash flows; however, investors often rely on reported earnings to help them estimate

\footnotetext{
${ }^{6}$ Agrawal and Chadha (2005) examine cumulative abnormal returns (CARs) over 2 years prior to, and 1 year after, restatement announcements. Badertscher, Collins, and Lys (2007) show CARs for 240 trading days before and 820 trading days after the beginning of the 1 st restated period. Frieder and Shanthikumar (2007) show CARs for the period of 252 trading days before and after restatement and calculate various measures of abnormal returns for the month before restatement.

${ }^{7} \mathrm{We}$ start the error period at the beginning of the 1 st restated financial reporting period rather than the announcement of earnings for this period for several reasons. First, we would lose observations because of missing earnings announcement dates in Compustat/Institutional Brokers' Estimate System (IBES). Second, management provides earnings guidance ahead of earnings announcements, and investors' behavior even before the announcement of incorrect earnings can reflect their ability to see through mistakes or be fooled by them, especially if competing firms announce their earnings before the subject firm. Moreover, the reader can visually "move" point $D_{0}^{\mathrm{MISTAKE}}$ on all graphs by 120 days/4 months so that $D_{0}^{\text {MISTAKE }}$ corresponds to the approximate point of the announcement of the 1 st misstated quarter.
} 
FIGURE 1

Restatement Time Line

In Figure 1, the restatement time line is presented.

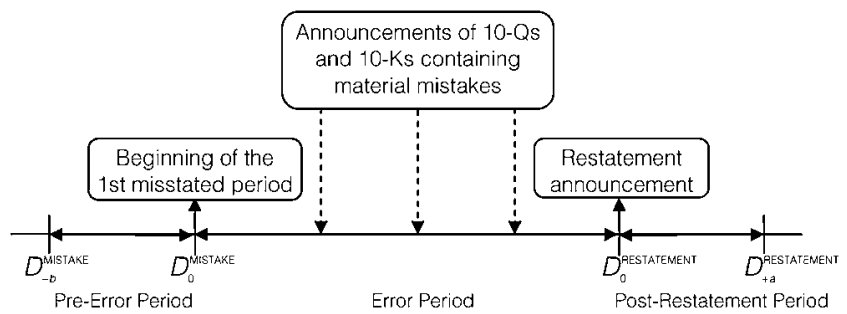

expected cash flows. Graham, Harvey, and Rajgopal (2005) document that the majority of firms view earnings as the key metric for an external audience, more so than cash flows. Earnings are also used as part of price earnings ratios, a widely used valuation method of stock analysts (see Block (1999)). Therefore, reporting erroneous earnings could lead investors to over- or undervalue stocks.

\section{B. Short-Term Market Reaction to the Announcement of Misstated Earnings ${ }^{8}$}

Investors do not rely solely on reported earnings; they estimate firms' earnings and future prospects using other information sources. Industry and government statistics, competitors' earnings announcements, and suppliers' and customers' information all help investors make accurate estimates of earnings prior to financial statement releases. Although investors are unlikely to completely ignore firms' misstated earnings, earnings that diverge significantly from those implied by other information sources could be partially discounted by investors.

Beaver (1968), Landsman and Maydew (2002), Ball and Kothari (1991), Chari, Jagannathan, and Ofer (1988), and Cohen, Dey, Lys, and Sunder (2007) have established that news announcements revealed to investors prior to financial reports do not fully preempt them. But the degree to which investors rely on reported earnings is still an open issue.

To determine how much investors are initially misled by misstated earnings, we first examine short-term market reaction to the initial announcement of incorrect earnings. Starting with Ball and Brown (1968), prior literature has shown that earnings announcement returns are a positive function of how much earnings deviate from expectations. ${ }^{9}$ The standard test of the relation is

$$
R_{t}=\alpha+b_{1}\left(I_{t}-\mathrm{E}_{t-1}\left(I_{t}\right)\right)+\varepsilon_{t}=\alpha+b_{1} \mathrm{SUE}_{t}+\varepsilon_{t},
$$

where $R_{t}$ is the abnormal return at the earnings announcement at time $t, I_{t}$ is the firm's correctly stated net income at time $t$, and $\mathrm{E}_{t-1}\left(I_{t}\right)$ is the market's expectation of net income just prior to the earnings announcement. Here, $I_{t}-\mathrm{E}_{t-1}\left(I_{t}\right)$

\footnotetext{
${ }^{8} \mathrm{We}$ thank an anonymous referee for suggesting that we analyze short-term reaction to the initial announcement of misstated earnings.

${ }^{9}$ See also Collins and Kothari (1989), Livnat and Mendenhall (2006), among others.
} 
is called the unexpected earnings. Both earnings and expected earnings are measured on a per share basis and are standardized by dividing by the stock price; the result is called the standardized unexpected earnings (SUE). The coefficient $b_{1}$ is called the earnings response coefficient.

If investors are misled by earnings mistakes, overstatements (understatements) should lead to larger (smaller) abnormal announcement returns than equation (1) predicts. We study this relation with

$$
\begin{aligned}
R_{t} & =\alpha+b_{1}\left(I_{t}-\mathrm{E}_{t-1}\left(I_{t}\right)\right)+b_{2} M_{t}+\varepsilon_{t} \\
& =\alpha+b_{1} \mathrm{SUE}_{t}+b_{2} \mathrm{MISTAKE}_{t}+\varepsilon_{t},
\end{aligned}
$$

where $M_{t}$ (MISTAKE) is the amount by which earnings are misstated. ${ }^{10}$ If investors see through the error, then $b_{2}$ should equal 0 . If investors are misled by the reporting error, then $b_{2}$ should be positive. If $b_{2}$ equals $b_{1}$, then investors are completely fooled and treat the misstated component of earnings the same way that they treat the correctly stated component. If $b_{2}>0$ and $b_{2}<b_{1}$, then investors are only partly fooled.

We estimate equation (2) for our sample of restating firms and for control firms matched to restating firms based on size, book-to-market, and industry (3-digit North American Industry Classification System (NAICS) code). Since the focus of most of our analysis is the error period, the match is performed just before the error period in year $m-1$, where $m$ is the fiscal year of a firm's 1 st mistake. ${ }^{11}$ First, for each firm we limit potential control firms to those with the same 3-digit NAICS code. ${ }^{12}$ Next, we find the closest firm in size and bookto-market using the method proposed by Lyon, Barber, and Tsai (1999), which is widely used in the literature, first identifying all potential control firms with size between $70 \%$ and $130 \%$ of that of the restating firm, and then choosing the one with the book-to-market value closest to that of the restating firm. ${ }^{13}$ Size is measured by the market value of equity at $m-1$. Book-to-market ratio is calculated as the ratio of book equity to market equity at $m-1$. We eliminate all restating firms from the pool of potential control firms. We also require control firms to have Center for Research in Security Prices (CRSP) returns for at

\footnotetext{
${ }^{10}$ For notational simplicity, in equation (2) and subsequent related equations, we do not explicitly show the standardization adjustment. In all cases, earnings $\left(I_{t}\right)$, expected earnings $\mathrm{E}_{t-1}\left[I_{t}\right]$, and the mistake $M_{t}$, are per share numbers standardized by dividing by the stock price at $t$.

${ }^{11}$ The matching is based on fiscal, not calendar year. For example, if a firm's fiscal year ends on March 31 and it made the 1st mistake in the year ending March 31, 1999, then the size and book-tomarket for period $m-1$ correspond to the year of March 31, 1998 (in Compustat, fiscal year 1997). The matching firm is then found based on size and book-to-market ratios calculated for 1997 fiscal year irrespective of the month of the fiscal year-end for the matching firm.

${ }^{12}$ A number of studies suggest the importance of matching on industry (Kahle and Walkling (1996), Barber and Lyon (1997)). Matching on industry is particularly important for this study because accounting rules vary by industry, and our sample includes financials and utilities.

${ }^{13}$ For 30 restating firms, there were no controls that satisfied data requirements. For these firms, we chose a control firm that is the closest in size within 3-digit NAICS code. The difference in size of control firms for this group and restating firms ranges between $32 \%$ and $158 \%$ of the size of the restating firms, with a mean of 59\% and a median of 54\%. For 2 restating firms, control firms were found as the closest in size within 2-digit NAICS code.
} 
least as many trading days as the corresponding restating firm 1 year prior to the matched restating firm's mistake date and 1 year subsequent to the restatement date.

For restating firms, we hand collected originally reported and restated earnings from restatement announcements and SEC filings for every earnings announcement that occurred during the error period. ${ }^{14}$ For control firms, we use earnings data from IBES. To make right-hand-side variables comparable across firms, we use earnings per share (EPS) numbers scaled by stock price at the end of the quarter. We use IBES consensus analyst forecasts immediately prior to the earnings announcement as expected earnings. Following Livnat and Mendenhall (2006), we calculate consensus analyst forecasts as the median of forecasts reported to IBES in the 90 days prior to the earnings announcement, considering only the most recent forecast for each analyst.

Bradshaw and Sloan (2002) show that investors price the Street earnings numbers reported by analyst tracking services, such as IBES, rather than the earnings numbers reported under generally accepted accounting principles (GAAP). Street earnings exclude certain expenses, such as special items and noncash items, from GAAP earnings. Bradshaw and Sloan show that Street earnings reported in IBES are more directly comparable with analysts' forecasts and therefore provide a better measure of the true earnings surprise associated with an announcement. To determine actual earnings $\left(I_{t}\right.$ in equation (2)), we start with originally reported Street earnings obtained from IBES and adjust that by the mistake to calculate $I_{t}$ and SUE in equation (2). ${ }^{15}$ Here, $R_{t}$ is market-adjusted return for a 3 -day window $(-1,+1)$ relative to the earnings announcement on day 0 . We use the value-weighted CRSP market index as a proxy for the market return. ${ }^{16}$ Earnings announcement dates are from IBES. We cluster standard errors by industry (3-digit NAICS code) to account for correlation of observations for firms in the same industry. ${ }^{17}$

\footnotetext{
${ }^{14}$ For example, a firm that restated 2 years will have 8 quarterly earnings announcements during its error period (if all data are available).

${ }^{15}$ We subtract the amount of the mistake in GAAP EPS from IBES earnings to obtain restated Street earnings. Such calculation assumes that a mistake was made in accounts that are not subtracted from GAAP earnings when calculating Street earnings. To check the robustness of results reported in the paper, we perform 3 additional tests. First, whenever GAAP earnings do not equal Street earnings, we eliminate observations for which restatement affected noncore accounts. Thus, we delete observations for which the mistake could have occurred in one of the accounts that is deducted to get to Street earnings. This results in a sample of 357 observations for restating firms (68\% of 553 observations with available data for estimating equation (2)). Second, whenever GAAP earnings do not equal Street earnings and the restatement did not affect core accounts, we set the mistake equal to 0 instead of deleting these observations. Third, we restrict the sample to firms for which GAAP and Street earnings are the same (55\% of 553 restating firm observations with available data for estimating equation (2)). All approaches yield coefficients of the same sign and similar magnitude and significance. Inference regarding the difference between the coefficient estimates is also the same.

${ }^{16}$ Our results are very similar using the equal-weighted index and market model-adjusted returns. For market model-adjusted returns we use standard event study methodology and estimate the market model for a 1 -year period starting on day -46 relative to earnings announcement using CRSP market index. We reported results using market-adjusted returns because we lose fewer observations when calculating returns this way.

${ }^{17}$ Our results are robust to clustering standard errors by restatement.
} 


\section{Long-Run Valuation of Restating Firms}

If investors are misled by erroneous financial statements, they could misvalue stocks for as long as the misinformation persists during the error period. We examine abnormal returns measured over different parts of the error period to shed light on this issue. Misvaluation is measured in 2 ways: CARs defined relative to the overall market, and buy-and-hold abnormal returns (BHARs) defined relative to a sample of control firms matched by size, book-to-market, and industry.

If mistakes in financial reporting allow restating firms to exceed (meet) investor's expectations and investors do not see through the financial reports, abnormal returns in the error period should be positive (0). Negative abnormal returns in the error period for a firm that is reporting that it exceeded investor expectations (when actual results were less than expected) would suggest that investors see through overstated earnings. Because investors' perceptions of true earnings and the associated abnormal returns could change during the error period, we split the error period into quartiles (where each quartile represents $1 / 4$ of the error period and is firm specific).

Our analysis of the ability of the market, and hence the marginal investor, to anticipate restatements is related to prior literature that studied the trading behavior of sophisticated investors preceding restatements. For example, Efendi, Kinney, and Swanson (2004) and Desai, Krishnamurthy, and Venkataraman (2006) show that short interest increases prior to restatements and declines thereafter, and the larger the short interest, the larger the short-term stock price decline at the restatement announcement. These studies examine fixed time intervals prior to the restatement date instead of defining the precise error periods for each firm. They do not show whether short seller trading causes negative returns, or if negative returns cause short sellers to sell shares of restating firms. Agrawal and Cooper (2007) show that insiders sell more shares before restatements, and Hribar, Jenkins, and Wang (2005) and Frieder and Shanthikumar (2007) find that large and institutional investors decrease their stock holdings before restatement announcements. Griffin (2003) finds that insiders and short sellers predict corrective disclosures (including restatements) that led to class action lawsuits. ${ }^{18}$ These studies' results are consistent with the notion that sophisticated investors anticipate restatements.

All of these studies used the Government Accountability Office (formerly General Accounting Office (GAO) (2002)) sample of restatements. The GAO sample includes many restatements due to changes in accounting standards (e.g., Financial Accounting Standards Board (FASB) 101, FASB 142, and others) that do not necessarily represent an accounting error and can be more easily anticipated. We reviewed all restatements and deleted restatements that were caused by a change in accounting standards and did not correct an accounting error.

\footnotetext{
${ }^{18}$ Securities class action lawsuits filed under Rule 10b-5 allege material flaws pertaining to firms' disclosure. Allegedly, firms' misstatements cause inflation in the stock price during the class action period. Most of these lawsuits are filed on behalf of shareholders who bought the stock during the period of inflated stock prices and are entitled to compensation.
} 


\section{Data}

Restatement dates and restatement characteristics were hand collected from the Lexis-Nexis and Factiva databases. The Lexis-Nexis and Factiva databases were researched using key words "restatement," "restat," "revis," "adjust," "error," and "responding to guidance from the SEC" for the period January 1, 1997-June 30, 2002. We selected this period for 2 reasons. First, the GAO (2002) made a sample of restatements announced in this period publicly available. Second, all restatements precede the Sarbanes-Oxley Act. Therefore, all restatements in our sample were made in the same regulatory environment. We cross-checked our sample with the GAO sample and added all restatements in the GAO sample that were not identified by the Lexis-Nexis search. Panels A and B of Table 1 compare our sample to that of the GAO and present the reasons for deleting GAO restatements. Overall, we deleted 431 restatements out of the total of 918 restatements in the GAO sample. We excluded restatements that were caused by an adoption of new accounting rules or a change in method of accounting (130 restatements), and retained only restatements due to a mistake (including fraud) or an improper interpretation of GAAP. We also deleted restatements that affected only the timing of item recognition and had no impact on annual net income (44 restatements). In addition, we deleted restatements if we were unable to obtain the necessary firm data from CRSP and Compustat (187 restatements).

This procedure resulted in 492 restatements made by 465 firms (Panel C of Table 1). Most of the firms $(95 \%)$ restate their financial reports only once in the sample period. After identifying the sample of companies announcing restatements, we collected additional data on the restatements from the firms' amended SEC reports (Forms 10-K/A(s) and 10-Q/A(s)), including: date of the restatement announcement, years and quarters restated, and original and restated net income in each period. Because the reporting of restatements is very heterogeneous, we had to consult multiple sources to find all necessary information. Some firms reported the impact of a restatement on earnings in the restatement announcement, while some reported the impact in a footnote in their 10-Ks filed subsequent to their restatement announcement dates. Some firms filed amended 10-Qs for all restated periods, while others restated net income and EPS in 10-Qs filed after the restated period. The originally reported numbers were collected from originally filed 10-Qs. Collecting this data required reviewing each restating firm's financial reports filed both before and after the restatement announcement.

Panels A and B of Table 2 report sample characteristics for the fiscal yearend preceding the year or quarter of the 1st mistake $(m-1)$ and for the 1st year after the restatement announcement $(r+1)$. In the year preceding a mistake, our average firm has a mean market value of $\$ 2.03$ billion, a mean book value of assets of $\$ 1.92$ billion, a mean book-to-market ratio of 0.52 , and a mean ratio of long-term debt to total assets of $18 \%$. Comparison of data in Panels A and B suggests that market value decreases subsequent to restatement, while leverage remains unchanged.

Table 2 also reports statistics for the year prior to restatement (Panel C). The problem with this year is that it belongs to the pre-error period for firms restating less than 1 year and to the error period for firms restating more than 


\section{TABLE 1}

\section{Sample Description}

Restatement dates and characteristics were hand collected from the Lexis-Nexis and Factiva databases. The Lexis-Nexis and Factiva databases were researched using key words "restatement," "restat," "revis," "adjust," "error," and "responding to guidance from the SEC" during the period January 1, 1997-June 30, 2002. We cross-checked our sample with the sample released by the GAO (2002). Unlike the GAO sample, we exclude restatements that were caused by the adoption of new accounting rules, and retain only restatements due to a mistake or an improper interpretation of GAAP rules.

Panel A. Sample Selection

\begin{tabular}{l} 
Source \\
\hline GAO sample \\
Less deleted restatements \\
Plus additional restatements \\
Total sample \\
$\begin{array}{l}\text { Panel B. Reasons for Deleting GAO Restatements } \\
\text { Reason for Deleting }\end{array}$ \\
\hline
\end{tabular}

Number of Restatements

New rule adoption

In the sample period, companies adopted the following rules: FASB 101, FASB 133,

EIC-113, EITF 00-10, EITF 00-14, FASB 142, etc. Approximately $50 \%$ of new rule adop-

tion restatements are due to adoption of FASB 101 revenue recognition rule.

Change in method of accounting

No restatement was made despite the announcement of a possibility of a restatement

No information found regarding restatement

Restatement due to timing

Other

Sixteen of the restatement announcements in the GAO sample were not announcements of new restatements, but rather releases of new information regarding already announced restatements. This category also includes restatements that were not a result of a mistake or a misinterpretation of accounting rules (e.g., restatements due to changes in the number of shares).

Total number of deleted restatements

918

492

Number of Restatements

Panel C. Number of Restatements and Restating Firms

Number of Restatements by the Same Firm in the Sample Period

Number of

\begin{tabular}{r} 
Restating Firms \\
\hline 441 \\
21 \\
3 \\
465
\end{tabular}

Number of Restatements

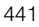

42

9

492

Total

Panel D. Restatements by Year

\begin{tabular}{l} 
Year \\
\hline 1997 \\
1998 \\
1999 \\
2000 \\
2001 \\
2002 (through June 30, 2002) \\
Total
\end{tabular}

Number of Restatements

63

64

111

109

76

69

492

1 year. However, many prior studies analyzing restating firms report descriptive statistics for this year. We include Panel C to make our sample comparable to prior studies. ${ }^{19}$ All of the rest of our analysis carefully separates pre-error, error, and post-restatement periods.

\footnotetext{
${ }^{19}$ Panel $\mathrm{C}$ of Table 2 shows that the mean book value of assets as reported at the fiscal year-end prior to the restatement announcement $(r-1)$ is $\$ 2.60$ billion, compared to $\$ 1.14$ billion for the sample of 403 restatements made between 1995 and 1999, analyzed by Palmrose et al. (2004). The mean (median) ratio of long-term debt to total assets is $19 \%$ (14\%) for our sample, compared to $21 \%$ (6\%) for Palmrose et al.
} 
TABLE 2

Characteristics of Restating Firms at Different Points in Time Relative to Mistakes and Restatements

Market value is the market value of equity calculated as stock price multiplied by number of shares outstanding. Bookto-market ratio is calculated as the ratio of book value divided by the market value of common equity. Leverage is the value of long-term debt divided by total assets. Core is a dummy variable that equals 1 if revenue or expense accounts were restated. Fraud is a dummy variable that equals 1 if the company announced fraud as a reason for restatement. In Panel B, we excluded 2 outliers with book-to-market equal to -436 and -292 when reporting statistics for book-to-market.

Panel A. Year-1 Relative to Mistake

\begin{tabular}{|c|c|c|}
\hline Variable & Mean & Maximum \\
\hline Market value (mil) & $\$ 2,032$ & $\$ 131,717$ \\
\hline Total assets (mil) & $\$ 1,916$ & $\$ 105,130$ \\
\hline Book-to-market & 0.52 & 4.42 \\
\hline Leverage & 0.18 & 1.66 \\
\hline \multicolumn{3}{|c|}{ Panel B. Year +1 Relative to Restatement } \\
\hline
\end{tabular}

\begin{tabular}{|c|c|}
\hline Minimum & $\begin{array}{l}\text { Standard } \\
\text { Deviation }\end{array}$ \\
\hline$\$ 4$ & $\$ 10,012$ \\
\hline$\$ 1$ & $\$ 8,427$ \\
\hline-2.11 & 0.55 \\
\hline 0.00 & 0.22 \\
\hline
\end{tabular}

\begin{tabular}{l}
$\begin{array}{c}\text { Lower } \\
\text { Quartile }\end{array}$ \\
\hline$\$ 46$ \\
$\$ 37$ \\
0.21 \\
0.00
\end{tabular}

\begin{tabular}{|c|c|c|}
\hline Median & $\begin{array}{c}\text { Upper } \\
\text { Quartile }\end{array}$ & $N$ \\
\hline$\$ 173$ & $\$ 738$ & 442 \\
\hline$\$ 141$ & $\$ 764$ & 469 \\
\hline 0.40 & 0.71 & 441 \\
\hline 0.12 & 0.28 & 466 \\
\hline
\end{tabular}

\begin{tabular}{|c|c|c|}
\hline Variable & Mean & Maximum \\
\hline Market value (mil) & $\$ 2,064$ & $\$ 115,268$ \\
\hline Total assets (mil) & $\$ 2,452$ & $\$ 93,170$ \\
\hline Book-to-market & 0.30 & 9.47 \\
\hline Leverage & 0.18 & 2.85 \\
\hline
\end{tabular}

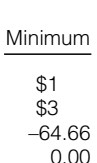

\begin{tabular}{c}
$\begin{array}{c}\text { Standard } \\
\text { Deviation }\end{array}$ \\
\hline$\$ 9,595$ \\
$\$ 8,872$ \\
4.84 \\
0.24
\end{tabular}

\begin{tabular}{c} 
Lower \\
Quartile \\
\hline$\$ 24$ \\
$\$ 50$ \\
0.24 \\
0.01
\end{tabular}

\begin{tabular}{|c|c|}
\hline Median & $\begin{array}{c}\text { Upper } \\
\text { Quartile }\end{array}$ \\
\hline$\$ 95$ & $\$ 435$ \\
\hline$\$ 201$ & $\$ 1,148$ \\
\hline 0.54 & 1.09 \\
\hline 0.11 & 0.29 \\
\hline
\end{tabular}

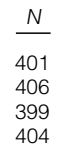

Panel C. Year-1 Relative to Restatement

\begin{tabular}{lcc}
\multicolumn{1}{c}{ Variable } & & Mean \\
\cline { 3 - 3 } Market value (mil) & & $\$ 2,210$ \\
Total assets (mil) & & $\$ 2,600$ \\
Book-to-market & 0.65 \\
Leverage & 0.19 \\
Panel D. Exchange Listing
\end{tabular}

\begin{tabular}{c} 
Maximum \\
\hline$\$ 112,194$ \\
$\$ 112,839$ \\
14.64 \\
1.66
\end{tabular}

\begin{tabular}{c} 
Minimum \\
\hline$\$ 2$ \\
$\$ 2$ \\
-2.90 \\
0.00
\end{tabular}

\begin{tabular}{ccc}
$\begin{array}{cc}\text { Standard } \\
\text { Deviation }\end{array}$ & & $\begin{array}{c}\text { Lower } \\
\text { Quartile }\end{array}$ \\
\cline { 1 - 1 }$\$ 9,201$ & & $\$ 44$ \\
$\$ 10,142$ & & $\$ 55$ \\
0.97 & & 0.19 \\
0.20 & & 0.01
\end{tabular}

\begin{tabular}{l} 
Median \\
\hline$\$ 179$ \\
$\$ 223$ \\
0.46 \\
0.14
\end{tabular}

\begin{tabular}{ccc}
$\begin{array}{cc}\text { Upper } \\
\text { Quartile }\end{array}$ & & $N$ \\
\cline { 1 - 1 }$\$ 681$ & & 462 \\
$\$ 1,093$ & & 466 \\
0.85 & & 461 \\
0.29 & & 464
\end{tabular}

Exchange

NYSE

NASDAQ

AMEX

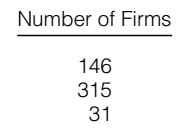

As a $\%$

$29.67 \%$

$64.02 \%$ $6.30 \%$

Panel E. Restatement Characteristics

\begin{tabular}{lrrrr} 
Variable & Yes & As a $\%$ & No & As a \% \\
\cline { 3 - 5 } Fraud & 57 & $11.59 \%$ & 435 & $88.41 \%$ \\
Core & 272 & $50.75 \%$ & 264 & $49.25 \%$ \\
\hline
\end{tabular}

The majority of restating firms are listed on the NASDAQ (64.0\%), with $29.7 \%$ listed on the NYSE (Panel D of Table 2). In 12\% of our observations, the firm announced that the restatement was due to fraud (Panel E of Table 2). Our definition of fraudulent behavior is conservative because it is based solely on self-reported fraud and potentially omits instances of fraud that are only revealed by subsequent investigations. Approximately $1 / 2$ of the restatements impact core accounts, such as revenue and expense (Panel E of Table 2).

Table 3 presents the distribution of restatements by industry (3-digit NAICS code). The following 5 industries account for $40 \%$ of all restatements in our sample period: i) computer and electronic product manufacturing; ii) publishing industries (except Internet); iii) credit intermediation and related activities; iv) professional, scientific, and technical services; and v) machinery manufacturing.

Table 4 presents summary statistics for the length of the error period and the number of years restated. The number of years restated is the number of years in 
TABLE 3

Distribution of Restatements by Industry $(N=492)$

In Table 3 the distribution of restatements are presented by industry.

NAICS

Code

334

511

522

541

333

336

325

524

339

561

518

311

423

221

513

512

517

562

315

331

446

514

523

525

623

211

326

421

424

448

322

332

337

422

443

488

621

713

722

324

327

335

445

484

532

611

\section{Code Description}

Computer and electronic product manufacturing

Publishing industries (except Internet)

Credit intermediation and related activities

Professional, scientific, and technical services

Machinery manufacturing

Transportation equipment manufacturing

Chemical manufacturing

Insurance carriers and related activities

Miscellaneous manufacturing

Administrative and support services

Data processing, hosting, and related services

Food manufacturing

Merchant wholesalers, durable goods

Utilities

Broadcasting and telecommunications

Motion picture and sound recording industries

Telecommunications

Waste management and remediation services

Apparel manufacturing

Primary metal manufacturing

Health and personal care stores

Information services and data processing services

Securities, commodity contracts, and other financial investments

Funds, trusts, and other financial vehicles

Nursing and residential care facilities

Oil and gas extraction

Plastics and rubber products manufacturing

Wholesale trade, durable goods

Merchant wholesalers, nondurable goods

Clothing and clothing accessories stores

Paper manufacturing

Fabricated metal product manufacturing

Furniture and related product manufacturing

Wholesale trade, nondurable goods

Electronics and appliance stores

Support activities for transportation

Ambulatory health care services

Amusement, gambling, and recreation industries

Food services and drinking places

Petroleum and coal products manufacturing

Nonmetallic mineral product manufacturing

Electrical equipment, appliance, and component manufacturing

Food and beverage stores

Truck transportation

Rental and leasing services

Educational services

Industrial conglomerates and multi-sector holdings

Mining (except oil and gas)

Support activities for mining

Construction of buildings

Heavy and civil engineering construction

Beverage and tobacco product manufacturing

Leather and allied product manufacturing

Printing and related support activities

General merchandise stores

Accommodation

Building, developing, and general contracting

Special trade contractors

Textile mills

Textile product mills

Motor vehicle and parts dealers

Furniture and home furnishings stores

Building material and garden equipment and supplies dealers

Gasoline stations

Sporting goods, hobby, book, and music stores

Nonstore retailers
Number of

Restatements

66

$\%$

$13.4 \%$

$49-10.0 \%$

$35 \quad 7.1 \%$

$27 \quad 5.5 \%$

$16-3.3 \%$

$15 \quad 3.0 \%$

$14 \quad 2.8 \%$

$2.8 \%$

$2.6 \%$

$2.4 \%$

$2.2 \%$

$1.8 \%$

$1.8 \%$

$1.6 \%$

$1.6 \%$

$1.4 \%$

$1.4 \%$

$1.4 \%$

$1.2 \%$

$1.2 \%$

$1.2 \%$

$1.2 \%$

$1.2 \%$

$1.2 \%$

$1.2 \%$

$1.0 \%$

$1.0 \%$

$1.0 \%$

$1.0 \%$

$1.0 \%$

$0.8 \%$

$0.8 \%$

$0.8 \%$

$0.8 \%$

$0.8 \%$

$0.8 \%$

$0.8 \%$

$0.8 \%$

$0.8 \%$

$0.6 \%$

$0.6 \%$

$0.6 \%$

$0.6 \%$

$0.6 \%$

$0.6 \%$

$0.6 \%$

$0.6 \%$

$0.4 \%$

$0.4 \%$

$0.4 \%$

$0.4 \%$

$0.4 \%$

$0.4 \%$

$0.4 \%$

$0.4 \%$

$0.4 \%$

$0.2 \%$

$0.2 \%$

$0.2 \%$

$0.2 \%$

$0.2 \%$

$0.2 \%$

$0.2 \%$

$0.2 \%$

$0.2 \%$

$0.2 \%$ 
TABLE 3 (continued)

Distribution of Restatements by Industry $(N=492)$

\begin{tabular}{|c|c|c|c|}
\hline $\begin{array}{l}\text { NAICS } \\
\text { Code } \\
\end{array}$ & Code Description & $\begin{array}{c}\text { Number of } \\
\text { Restatements }\end{array}$ & $\%$ \\
\hline 483 & Water transportation & 1 & $0.2 \%$ \\
\hline 485 & Transit and ground passenger transportation & 1 & $0.2 \%$ \\
\hline 492 & Couriers and messengers & 1 & $0.2 \%$ \\
\hline 531 & Real estate & 1 & $0.2 \%$ \\
\hline 533 & Lessors of nonfinancial intangible assets & 1 & $0.2 \%$ \\
\hline 622 & Hospitals & 1 & $0.2 \%$ \\
\hline 624 & Social assistance & 1 & $0.2 \%$ \\
\hline 711 & Performing arts, spectator sports, and related industries & 1 & $0.2 \%$ \\
\hline 811 & Repair and maintenance & 1 & $0.2 \%$ \\
\hline 812 & Personal and laundry services & 1 & $0.2 \%$ \\
\hline
\end{tabular}

TABLE 4

Distribution of the Length of the Error Period and the Number of Restated Years

The Error Period is defined as the period that extends from the 1st misstated period to the day of restatement announcement. For example, if the company made a mistake in 1997 and announced a restatement of its 1997 annual report on March 15, 1998, the error period would span January 1, 1997-March 15, 1998 and equal 1.20 years. The Number of Restated Years is the number of years in which the company made a mistake. Quarterly restatements are defined as restatements of quarterly financial statements only and no restatement of an annual (audited) report. Annual restatements include a restatement of at least 1 annual (audited) report. Downward (upward) restatements are defined as restatements that result in downward (upward) revision of net income.

\begin{tabular}{|c|c|c|c|c|c|c|c|c|}
\hline Sample & Mean & Maximum & Minimum & $\begin{array}{l}\text { Standard } \\
\text { Deviation } \\
\end{array}$ & $\begin{array}{l}\text { Lower } \\
\text { Quartile } \\
\end{array}$ & Median & $\begin{array}{c}\text { Upper } \\
\text { Quartile } \\
\end{array}$ & $N$ \\
\hline \multicolumn{9}{|l|}{ Panel A. Error Period } \\
\hline Full Sample & 1.89 & 6.83 & 0.27 & 1.21 & 0.94 & 1.62 & 2.62 & 492 \\
\hline Annual & 2.52 & 6.83 & 1.07 & 1.07 & 1.74 & 2.23 & 3.22 & 315 \\
\hline Quarterly & 0.79 & 1.38 & 0.27 & 0.29 & 0.57 & 0.82 & 1.02 & 177 \\
\hline Annual downward & 2.53 & 6.55 & 1.07 & 1.08 & 1.74 & 2.24 & 3.25 & 242 \\
\hline Quarterly downward & 0.79 & 1.38 & 0.27 & 0.29 & 0.57 & 0.82 & 1.03 & 140 \\
\hline Annual upward & 2.52 & 6.83 & 1.22 & 1.06 & 1.82 & 2.21 & 3.11 & 40 \\
\hline Quarterly upward & 0.81 & 1.29 & 0.32 & 0.27 & 0.61 & 0.83 & 1.01 & 20 \\
\hline \multicolumn{9}{|c|}{ Panel B. Number of Restated Years } \\
\hline Full Sample & 1.40 & 6.00 & 0.25 & 1.06 & 0.50 & 1.00 & 2.00 & 492 \\
\hline Annual & 1.94 & 6.00 & 1.00 & 0.96 & 1.00 & 1.75 & 2.75 & 315 \\
\hline Quarterly & 0.45 & 0.75 & 0.25 & 0.21 & 0.25 & 0.50 & 0.75 & 177 \\
\hline Annual downward & 1.96 & 6.00 & 1.00 & 0.97 & 1.00 & 1.75 & 2.75 & 242 \\
\hline Quarterly downward & 0.45 & 0.75 & 0.25 & 0.21 & 0.25 & 0.50 & 0.75 & 140 \\
\hline Annual upward & 1.93 & 5.50 & 1.00 & 0.94 & 1.00 & 1.75 & 2.38 & 40 \\
\hline Quarterly upward & 0.48 & 0.75 & 0.25 & 0.20 & 0.25 & 0.50 & 0.63 & 20 \\
\hline
\end{tabular}

which the company made a mistake and reported erroneous earnings. The number of restated years is always less than or equal to the length of the error period. Table 4 also gives statistics for the length of the error period and the number of restated years for subsamples of quarterly and annual restatements. Quarterly restatements are defined as restatements of quarterly financial statements only and not restatements of an annual (audited) report. Annual restatements include a restatement of at least one annual (audited) report. Sixty-three percent of restatements in our sample are annual restatements. The average number of periods restated is approximately $1 / 2$ a year in the quarterly subsample and 2 years in the annual subsample. The average length of the error period is 1.89 years for the full sample, and 2.52 years and 0.79 years for annual and quarterly restatements, respectively (Panel A of Table 4). The average number of years restated is 


\section{TABLE 5}

Impact of Restatement on Net Income

Panel A of Table 5 reports statistics for the difference between net income per share as restated (summed over the error period) and net income per share as originally reported (summed over the error period) divided by stock price 360 calendar days prior to restatement announcement. Panel B reports statistics for the difference between restated net income (summed over the error period) and originally reported net income (summed over the error period) divided by the absolute value of the originally reported net income (summed over the error period). Quarterly restatements are defined as restatements of quarterly financial statements only and no restatement of an annual (audited) report. Annual restatements include a restatement of at least 1 annual (audited) report. Downward (upward) restatements are defined as restatements that result in downward (upward) revision of net income.

\begin{tabular}{|c|c|c|c|c|c|c|c|c|}
\hline Sample & $\underline{\text { Mean }}$ & $\underline{\text { Maximum }}$ & $\underline{\text { Minimum }}$ & $\begin{array}{l}\text { Standard } \\
\text { Deviation } \\
\end{array}$ & $\begin{array}{l}\text { Lower } \\
\text { Quartile } \\
\end{array}$ & Median & $\begin{array}{c}\text { Upper } \\
\text { Quartile }\end{array}$ & $N$ \\
\hline \multicolumn{9}{|c|}{ Panel A. (Net Income Per Share Restated - Net Income Per Share Original) / Stock Price } \\
\hline $\begin{array}{l}\text { Full Sample } \\
\text { Annual } \\
\text { Quarterly }\end{array}$ & $\begin{array}{l}-0.03 \\
-0.04 \\
-0.02\end{array}$ & $\begin{array}{l}1.85 \\
1.85 \\
0.25\end{array}$ & $\begin{array}{l}-1.46 \\
-1.46 \\
-0.72\end{array}$ & $\begin{array}{l}0.15 \\
0.18 \\
0.09\end{array}$ & $\begin{array}{l}-0.03 \\
-0.05 \\
-0.02\end{array}$ & $\begin{array}{l}-0.01 \\
-0.01 \\
-0.01\end{array}$ & $\begin{array}{l}0.00 \\
0.00 \\
0.00\end{array}$ & $\begin{array}{l}434 \\
274 \\
160\end{array}$ \\
\hline $\begin{array}{l}\text { Downward } \\
\text { Annual downward } \\
\text { Quarterly downward }\end{array}$ & $\begin{array}{l}-0.05 \\
-0.06 \\
-0.03\end{array}$ & $\begin{array}{l}0.29 \\
0.29 \\
0.25\end{array}$ & $\begin{array}{l}-1.46 \\
-1.46 \\
-0.72\end{array}$ & $\begin{array}{l}0.12 \\
0.14 \\
0.09\end{array}$ & $\begin{array}{l}-0.05 \\
-0.07 \\
-0.03\end{array}$ & $\begin{array}{l}-0.01 \\
-0.02 \\
-0.01\end{array}$ & $\begin{array}{r}0.00 \\
-0.01 \\
0.00\end{array}$ & $\begin{array}{l}362 \\
225 \\
137\end{array}$ \\
\hline $\begin{array}{l}\text { Upward } \\
\text { Annual upward } \\
\text { Quarterly upward }\end{array}$ & $\begin{array}{l}0.07 \\
0.08 \\
0.03\end{array}$ & $\begin{array}{l}1.85 \\
1.85 \\
0.18\end{array}$ & $\begin{array}{r}-0.55 \\
-0.55 \\
0.00\end{array}$ & $\begin{array}{l}0.28 \\
0.33 \\
0.05\end{array}$ & $\begin{array}{l}0.00 \\
0.01 \\
0.00\end{array}$ & $\begin{array}{l}0.01 \\
0.02 \\
0.01\end{array}$ & $\begin{array}{l}0.06 \\
0.06 \\
0.03\end{array}$ & $\begin{array}{l}55 \\
37 \\
18\end{array}$ \\
\hline \multicolumn{9}{|c|}{ Panel B. (Net Income Restated - Net Income Original) / Absolute Value (Net Income Original) } \\
\hline $\begin{array}{l}\text { Full Sample } \\
\text { Annual } \\
\text { Quarterly }\end{array}$ & $\begin{array}{l}-2.37 \\
-1.32 \\
-4.22\end{array}$ & $\begin{array}{l}6.75 \\
1.76 \\
6.75\end{array}$ & $\begin{array}{l}-255.59 \\
-168.55 \\
-255.59\end{array}$ & $\begin{array}{l}15.40 \\
10.11 \\
21.75\end{array}$ & $\begin{array}{l}-0.79 \\
-0.67 \\
-1.48\end{array}$ & $\begin{array}{l}-0.26 \\
-0.18 \\
-0.42\end{array}$ & $\begin{array}{l}-0.05 \\
-0.04 \\
-0.06\end{array}$ & $\begin{array}{l}449 \\
287 \\
162\end{array}$ \\
\hline $\begin{array}{l}\text { Downward } \\
\text { Annual downward } \\
\text { Quarterly downward }\end{array}$ & $\begin{array}{l}-2.87 \\
-1.64 \\
-5.00\end{array}$ & $\begin{array}{l}-0.00 \\
-0.00 \\
-0.01\end{array}$ & $\begin{array}{l}-255.59 \\
-168.55 \\
-255.59\end{array}$ & $\begin{array}{l}16.65 \\
10.98 \\
23.31\end{array}$ & $\begin{array}{l}-1.028 \\
-0.76 \\
-2.09\end{array}$ & $\begin{array}{l}-0.36 \\
-0.29 \\
-0.50\end{array}$ & $\begin{array}{l}-0.10 \\
-0.08 \\
-0.16\end{array}$ & $\begin{array}{l}382 \\
242 \\
140\end{array}$ \\
\hline $\begin{array}{l}\text { Upward } \\
\text { Annual upward } \\
\text { Quarterly upward }\end{array}$ & $\begin{array}{l}0.58 \\
0.45 \\
0.83\end{array}$ & $\begin{array}{l}6.75 \\
1.76 \\
6.75\end{array}$ & $\begin{array}{l}0.01 \\
0.02 \\
0.02\end{array}$ & $\begin{array}{l}0.94 \\
0.47 \\
1.49\end{array}$ & $\begin{array}{l}0.08 \\
0.09 \\
0.07\end{array}$ & $\begin{array}{l}0.32 \\
0.23 \\
0.41\end{array}$ & $\begin{array}{l}0.76 \\
0.64 \\
0.96\end{array}$ & $\begin{array}{l}60 \\
40 \\
20\end{array}$ \\
\hline
\end{tabular}

1.4 years for the full sample, 1.94 for annual, and 0.45 for quarterly restatements (Panel B of Table 4). Statistics for upward and downward subsamples are similar.

Table 5 gives the impact of mistakes on net income per share scaled by stock price (Panel A) and percent change in net income as a result of a restatement (Panel B). If a firm restated more than 1 period, net income and net income per share are summed over the error period. Statistics in Panel B are much more skewed than those in Panel A. The majority of mistakes (85\%) overstate net income. Only 60 firms in our sample understate net income. Restatement of net income per share is of similar magnitude for annual and quarterly restatements, and for upward and downward restatements. However, the magnitude of the percent change in net income is larger for quarterly downward restatements than for annual downward restatements (Panel B).

\section{Results}

\section{A. Short-Term Market Reaction to the Announcement of Misstated Earnings}

Table 6 presents descriptive statistics for variables used to estimate equation (2). Panels A-C show statistics for restating plus control firms for full, annual, and quarterly samples, respectively. Panels D-F show statistics for restating firms 
TABLE 6

Descriptive Statistics

Table 6 reports descriptive statistics for variables used in the analysis in Table 7. SUE is the standardized unexpected earnings relative to analyst expectations. MISTAKE is the difference between restated and originally reported earnings and equals 0 for all control firms. Both SUE and MISTAKE are measured on a per share basis and standardized by the stock price at the end of the quarter. Here, $R_{t}$ is the market-adjusted return for a 3-day window $(-1,+1)$ relative to the earnings announcement on day 0 . We use the value-weighted CRSP market index as a proxy for the market return, and $R_{t}$, SUE, and MISTAKE are winsorized at $1 \%$ and $99 \%$.

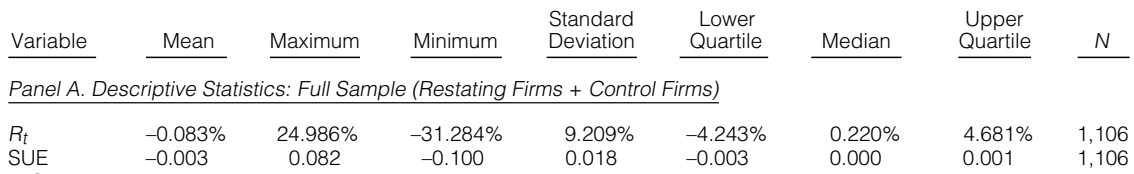

$\begin{array}{lrrrrrrr}\text { MISTAKE } & 0.002 & 0.072 & -0.052 & 0.011 & 0.000 & 0.000 & 0.001\end{array}$

Panel B. Descriptive Statistics: Annual Restatements (Restating Firms + Control Firms)

$\begin{array}{lccclclll}R_{t} & 0.094 \% & 24.986 \% & -31.284 \% & 8.576 \% & -3.882 \% & 0.252 \% & 4.540 \% & 812 \\ \text { SUE } & -0.002 & 0.082 & -0.100 & 0.017 & -0.002 & 0.000 & 0.001 & 812 \\ \text { MISTAKE } & 0.002 & 0.072 & -0.052 & 0.011 & 0.000 & 0.000 & 0.001 & 812\end{array}$

Panel C. Descriptive Statistics: Quarterly Restatements (Restating Firms + Control Firms)

\begin{tabular}{|c|c|c|c|c|c|c|c|c|}
\hline $\begin{array}{l}R_{t} \\
\text { SUE } \\
\text { MISTAKE }\end{array}$ & $\begin{array}{l}-0.573 \% \\
-0.004 \\
0.003\end{array}$ & $\begin{array}{c}24.986 \% \\
0.082 \\
0.072\end{array}$ & $\begin{array}{l}-31.284 \% \\
-0.100 \\
-0.052\end{array}$ & $\begin{array}{l}10.765 \% \\
0.021 \\
0.013\end{array}$ & $\begin{array}{c}-5.813 \% \\
-0.005 \\
0.000\end{array}$ & $\begin{array}{l}-0.150 \% \\
0.000 \\
0.000\end{array}$ & $\begin{array}{l}4.873 \% \\
0.001 \\
0.003\end{array}$ & $\begin{array}{l}294 \\
294 \\
294\end{array}$ \\
\hline \multicolumn{9}{|c|}{ Panel D. Descriptive Statistics: Full Sample (Restating Firms Only) } \\
\hline $\begin{array}{l}R_{t}^{t} \\
\text { SUE } \\
\text { MISTAKE }\end{array}$ & $\begin{array}{l}-0.244 \% \\
-0.006 \\
0.004\end{array}$ & $\begin{array}{c}24.986 \% \\
0.082 \\
0.072\end{array}$ & $\begin{array}{l}-31.284 \% \\
-0.100 \\
-0.052\end{array}$ & $\begin{array}{l}9.933 \% \\
0.024 \\
0.016\end{array}$ & $\begin{array}{c}-5.430 \% \\
-0.007 \\
0.000\end{array}$ & $\begin{array}{l}0.370 \% \\
-0.001 \\
0.001\end{array}$ & $\begin{array}{l}4.971 \% \\
0.000 \\
0.005\end{array}$ & $\begin{array}{l}553 \\
553 \\
553\end{array}$ \\
\hline \multicolumn{9}{|c|}{ Panel E. Descriptive Statistics: Annual Restatements (Restating Firms Only) } \\
\hline $\begin{array}{l}R_{t} \\
\text { SUE } \\
\text { MISTAKE }\end{array}$ & $\begin{array}{l}0.050 \% \\
-0.004 \\
0.003\end{array}$ & $\begin{array}{c}24.986 \% \\
0.082 \\
0.072\end{array}$ & $\begin{array}{l}-31.284 \% \\
-0.100 \\
-0.052\end{array}$ & $\begin{array}{l}8.978 \% \\
0.022 \\
0.015\end{array}$ & $\begin{array}{c}-4.614 \% \\
-0.005 \\
0.000\end{array}$ & $\begin{array}{c}0.624 \% \\
-0.001 \\
0.001\end{array}$ & $\begin{array}{l}4.973 \% \\
0.001 \\
0.004\end{array}$ & $\begin{array}{l}406 \\
406 \\
406\end{array}$ \\
\hline \multicolumn{9}{|c|}{ Panel F. Descriptive Statistics: Quarterly Restatements (Restating Firms Only) } \\
\hline $\begin{array}{l}R_{t} \\
\text { SUE } \\
\text { MISTAKE }\end{array}$ & $\begin{array}{c}-1.056 \% \\
-0.010 \\
0.006\end{array}$ & $\begin{array}{c}24.986 \% \\
0.082 \\
0.072\end{array}$ & $\begin{array}{l}-31.284 \% \\
-0.100 \\
-0.052\end{array}$ & $\begin{array}{c}12.187 \% \\
0.027 \\
0.017\end{array}$ & $\begin{array}{l}-7.258 \% \\
-0.012 \\
0.000\end{array}$ & $\begin{array}{l}-0.979 \% \\
-0.003 \\
0.003\end{array}$ & $\begin{array}{l}4.971 \% \\
0.000 \\
0.009\end{array}$ & $\begin{array}{l}147 \\
147 \\
147\end{array}$ \\
\hline
\end{tabular}

only. Announcement period returns $R_{t}$ are not statistically significantly different from 0 in any of the panels. The mean earnings surprise is negative for all samples. Interestingly, median SUE and MISTAKE are of the same magnitude but opposite direction for all samples, suggesting that mistakes allowed the median company in our sample to meet analyst expectations. Here, 204 restating firm quarters (37\%) corresponding to 97 firms (55\%) would have fallen short of analyst expectations had they not misstated financial statements. Both the mean and the median figures for MISTAKE are positive in all 6 panels. ${ }^{20}$

Model 1 (full sample) in Table 7 shows estimates of equation (2) for the combined samples of restating firms and control firms. The mistakes for control firms are assumed to be 0 . Consistent with prior literature, we find that the earnings response coefficient estimate is positive $\left(\bar{b}_{1}>0\right)$. The estimate of the effect of earnings mistakes $\left(\bar{b}_{2}\right)$ is also positive and significant, and it is not statistically different from $\bar{b}_{1}$. This result suggests that investors are misled by mistakes in financial statements at the announcement of original earnings. Investors

\footnotetext{
${ }^{20}$ MISTAKE is negative for 101 quarters.
} 


\section{TABLE 7}

Short-Term Market Reaction to Initial Announcement of Misstated Earnings

Models 1-3 of Table 7 estimate equation (2) for the sample of restating firms plus control firms matched on size, book-tomarket, and 3-digit NAICS code. Models 5-7 estimate equation (2) for restating firms only:

$$
R_{t}=a+b_{1} \mathrm{SUE}_{t}+b_{2} \mathrm{MISTAKE}_{t}+\varepsilon_{t} .
$$

Model 4 estimates equation (3) for annual restatements and their control firms:

(3) $R_{t}=a+b_{1}$ SUE $_{t}+b_{2}$ MISTAKE $_{t}+b_{3}$ DISTANCE_REST $_{t}+b_{4}$ DISTANCE_REST $_{t} \times$ MISTAKE $_{t}+\varepsilon_{t}$.

SUE is the standardized unexpected earnings relative to analyst expectations. MISTAKE is the difference between restated and originally reported earnings and equals 0 for all control firms. Both SUE and MISTAKE are measured on a per share basis and standardized by the stock price at the end of the quarter. Here, $R_{t}$ is the market-adjusted return for a 3-day window $(-1,+1)$ relative to the earnings announcement on day 0 . We use the value-weighted CRSP market index as a proxy for the market return. DISTANCE_REST measures the distance of the quarter from restatement announcement. For example, for the last quarterly earnings announcement of the error period DISTANCE_REST $=1$, for the quarterly earnings announcement before last DISTANCE_REST $=2$, etc. Here, $R_{t}$, SUE, and DISTANCE_REST are winsorized at $1 \%$ and $99 \%$, standard errors are clustered by industry (3-digit NAICS code). *, ${ }^{\star \star}$, and ${ }^{* \star *}$ indicates significance at the $10 \%, 5 \%$, and $1 \%$ levels, respectively.

\begin{tabular}{|c|c|c|c|c|c|c|c|}
\hline \multirow[b]{3}{*}{ Variable } & Model 1 & Model 2 & Model 3 & Model 4 & Model 5 & Model 6 & Model 7 \\
\hline & \multicolumn{4}{|c|}{ Restating Firms Plus Control Firms } & \multicolumn{3}{|c|}{ Restating Firms Only } \\
\hline & Full Sample & Annual & Quarterly & Annual & Full Sample & Annual & Quarterly \\
\hline Intercept & $\begin{array}{l}-0.0001 \\
(-0.04)\end{array}$ & $\begin{array}{l}0.0018 \\
(0.51)\end{array}$ & $\begin{array}{l}-0.0024 \\
(-0.46)\end{array}$ & $\begin{array}{l}0.0051 \\
(0.96)\end{array}$ & $\begin{array}{l}-0.0006 \\
(-0.14)\end{array}$ & $\begin{array}{c}0.001 \\
(0.22)\end{array}$ & $\begin{array}{l}-0.0055 \\
(-0.47)\end{array}$ \\
\hline SUE $\left(\bar{b}_{1}\right)$ & $\begin{array}{l}1.0758 \\
(2.84)^{\star \star \star}\end{array}$ & $\begin{array}{l}1.6206 \\
(3.71)^{* * \star}\end{array}$ & $\begin{array}{l}0.0342 \\
(0.08)\end{array}$ & $\begin{array}{l}1.6041 \\
(3.67)^{\star \star \star}\end{array}$ & $\begin{aligned} 0.8942 \\
(2.25)^{\star \star}\end{aligned}$ & $\begin{array}{l}1.035 \\
(3.21)^{\star \star \star}\end{array}$ & $\begin{array}{l}-0.2306 \\
(-0.25)\end{array}$ \\
\hline MISTAKE $\left(\bar{b}_{2}\right)$ & $\begin{array}{r}1.1691 \\
(2.47)^{\star \star}\end{array}$ & $\begin{array}{c}1.9503 \\
(3.10)^{* * \star}\end{array}$ & $\begin{array}{l}-0.9224 \\
(-1.32)\end{array}$ & $\begin{array}{r}1.3928 \\
(2.03)^{\star \star}\end{array}$ & $\begin{array}{c}0.9498 \\
(1.75)^{\star}\end{array}$ & $\begin{array}{c}1.5209 \\
(3.41)^{\star * *}\end{array}$ & $\begin{array}{l}-1.2452 \\
(-1.00)\end{array}$ \\
\hline DISTANCE_REST ( $\left.\bar{b}_{3}\right)$ & & & & $\begin{array}{l}-0.0008 \\
(-0.96)\end{array}$ & & & \\
\hline DISTANCE_REST $\times$ MISTAKE $\left(\bar{b}_{4}\right)$ & & & & $\begin{array}{c}0.1432 \\
(1.97)^{\star}\end{array}$ & & & \\
\hline $\begin{array}{l}N \\
\text { Adjusted } R^{2} \\
F\end{array}$ & $\begin{array}{l}1,106 \\
2.01 \% \\
4.04^{\star *}\end{array}$ & $\begin{array}{l}812 \\
4.01 \% \\
6.90^{\star \star \star}\end{array}$ & $\begin{array}{l}294 \\
1.32 \% \\
1.54\end{array}$ & $\begin{array}{c}812 \\
4.08 \% \\
4.62^{\star \star \star}\end{array}$ & $\begin{array}{l}553 \\
1.75 \% \\
2.65^{*}\end{array}$ & $\begin{array}{c}406 \\
3.85 \% \\
6.62^{\star \star \star}\end{array}$ & $\begin{array}{l}147 \\
1.42 \% \\
1.28\end{array}$ \\
\hline $\begin{array}{l}\bar{b}_{1}=\bar{b}_{2} \text { (t-value) } \\
\text { Number of restatements } \\
\text { Number of firms }\end{array}$ & $\begin{array}{r}(-0.37) \\
175 \\
163\end{array}$ & $\begin{array}{c}(-0.92) \\
93 \\
89\end{array}$ & $\begin{array}{l}(1.75)^{*} \\
82 \\
80\end{array}$ & $\begin{array}{c}(0.41) \\
93 \\
89\end{array}$ & $\begin{array}{r}(-0.21) \\
175 \\
163\end{array}$ & $\begin{array}{r}(-1.45) \\
93 \\
89\end{array}$ & $\begin{array}{c}(1.59) \\
82 \\
80\end{array}$ \\
\hline
\end{tabular}

apparently treat the misstated component of earnings as being equivalent to the true component of earnings.

We reestimate equation (2) separately for the annual and quarterly subsamples because annual restatements are deemed to be more serious. ${ }^{21}$ For the annual subsample, we again find $\bar{b}_{1}>0$ and $\bar{b}_{2}>0$, and the 2 estimates are not different from one another (Model 2 in Table 7). However, the quarterly sample produces statistically insignificant results (Model 3). The insignificant quarterly results could be due to the much smaller sample size and different nature of accounting irregularities. Overall, the evidence suggests that investors are misled by misstated earnings when they are initially announced for our sample of annual

\footnotetext{
${ }^{21}$ For both annual and quarterly subsamples, we examine market reaction to the announcement of quarterly earnings that took place during the error period. Note that for the annual subsample, we include announcements of quarters (10-Qs) in each restated year. Therefore, we are capturing earnings surprise for the entire year and not just the 4 th quarter.
} 
restatements. To ensure robustness of our results, we reestimate equation (2) for restating firms only (Models 5-7). The results are similar for all 3 samples.

We extend equation (2) to test whether investors anticipate accounting mistakes. We add an interaction between MISTAKE and a new variable, DISTANCE_ REST, which measures the distance of the quarter from the restatement announcement. For example, for the last quarterly (10-Q) earnings announcement of the error period, DISTANCE_REST $=1$, for the announcement of the quarterly report before that DISTANCE_REST $=2$, and so on. ${ }^{22}$ Equation (2) thus becomes

$$
\begin{aligned}
R_{t}= & a+b_{1} \mathrm{SUE}_{t}+b_{2} \mathrm{MISTAKE}_{t}+b_{3} \mathrm{DISTANCE} \_R E S T_{t} \\
& +b_{4} \mathrm{DISTANCE}_{\mathrm{REST}} \times \mathrm{MISTAKE}_{t}+\varepsilon_{t} .
\end{aligned}
$$

Model 4 in Table 7 shows that the estimate on the interaction $\bar{b}_{4}$ is positive and significant for the sample of restating and control firms, and for restating firms only, suggesting that investors attach a smaller valuation effect to mistakes made at the end of the error period compared to mistakes made at the beginning of the error period. Overall, as the restatement date approaches, investors are less and less fooled by the errors in reported earnings.

\section{B. Long-Run Valuation of Restating Firms}

Our analysis of market reaction to the initial announcement of restatements reveals that investors are misled by misstated earnings. To examine how long misvaluation persists, we analyze CARs and BHARs in the error period. We also examine CARs and BHARs of restating firms in the pre-error and post-restatement periods.

Graphs for CARs allow us to show trends in long-run returns and have been widely used in prior studies (Badertscher et al. (2007)). However, Barber and Lyon (1997) and Kothari and Warner (1997) document that event studies that rely on long-term CARs are misspecified, yielding excessive rejection levels. ${ }^{23}$ Barber and Lyon conclude that a conventional $t$-statistic applied to BHARs calculated using size and book-to-market matched control firms yields well-specified results in random samples. Lyon et al. (1999) also show that the size and book-tomarket matched control firm approach corrects reasonably well for cross-sectional dependence due to the relation between size, book-to-market ratios, and returns. Therefore, although we use graphs of long-term CARs to visually depict the trend in long-run returns, we perform all statistical tests using BHARs.

\footnotetext{
${ }^{22} \mathrm{~A}$ limitation of this approach is that only firms restating many quarters will have observations with large values of DISTANCE_REST. As a result, this variable can partly capture the effect of the number of periods restated. In the next section we use monthly BHARs to provide more specific evidence related to when investors start to anticipate a restatement.

${ }^{23}$ They note 3 main reasons for the misspecification: i) new listing or survivor bias, ii) rebalancing bias, and iii) skewness bias. New listing bias occurs when the control sample includes firms that begin trading subsequent to the event. Rebalancing bias arises when returns on the reference portfolio are calculated assuming periodic rebalancing, while the returns of the event firm are compounded without rebalancing. Skewness bias occurs when the distribution of long-run abnormal returns is positively skewed, inducing misspecification of test statistics.
} 


\section{Cumulative Abnormal Returns}

Figure 2 shows CARs around the mistake and the restatement for annual downward restatements. ${ }^{24}$ We can select the same fixed-length pre-error and postrestatement periods for all firms, but the error periods differ across firms. In plotting the abnormal returns over the error period, the longest period one can show for all firms in the sample is the minimum number of trading days during the error period, where the minimum is taken over all firms in the sample. As a result, the graph shows the minimum error period of 267 days for all firms, even though the error period is firm-specific. An important feature of the graph is that pre-error, error, and post-restatement periods are nonoverlapping. ${ }^{25}$

CARs are calculated as the difference between raw returns and market model predicted returns. Market model parameters are estimated for the period of 250 trading days ending on day -265 relative to the date of the mistake, in order to allow us to measure abnormal returns over the year prior to the mistake. Efendi, Srivastava, and Swanson (2007)) find an upward trend in CARs 12 months prior to the beginning of the error period. ${ }^{26}$ They suggest that managers could be motivated to overstate earnings in order to sustain superior performance, consistent with Jensen's (2005) theory of overvalued equity.

Figure 2 shows that restating firms have upward trending CARs in the preerror period, which continues into the early part of the error period. Control firms exhibit a downward trend the year before the mistake and bounce around the same level during the error and post-restatement periods. The positive trend in CARs and outperformance by restating firms relative to control firms in the 1st half of the error period are consistent with investors being misled by erroneous accounting statements. CARs for restating firms start to decline in the 2nd part of the error period, suggesting that investors begin to see through the errors. Restating firms' CARs subsequently fall below those of the control group, suggesting that investors penalize restating firms relative to control firms, perhaps because they anticipate restatement-related costs. Overall, the figure suggests that investors are misled during the beginning of the error period but catch on and partially anticipate the restatement announcement later in the period. Finally, looking at the post-restatement period, Figure 2 shows a slightly negative trend in CARs of restating firms compared to the control firms.

\section{Buy-and-Hold Abnormal Returns}

Next we examine BHARs for pre-error, error, and post-restatement periods. The error period gets most of our attention. Following Spiess and Affleck-Graves (1999) and others, we calculate a buy-and-hold return $\left(\mathrm{BHR}_{i, \tau}\right)$ over period $\tau$ for firm $i$ as the geometric return

\footnotetext{
${ }^{24}$ Since all of our statistical inference is drawn from BHARs, we show only one graph using CARs for our main sample to allow for the comparison to prior studies.

${ }^{25}$ Please see legend to Figure 2 for details of graph construction.

${ }^{26}$ Efendi et al. (2007) examine CARs of 95 firms restating earnings between January 1, 2001 and June 30, 2002.
} 
FIGURE 2

\section{CARs for Annual Downward Restatements}

Figure 2 plots cumulative abnormal returns (CARs) for 196 downward annual restatements with available data announced between January 1, 1997 and June 30, 2002, and their control firms. Abnormal returns are calculated as the difference between actual returns and market model predicted returns. Market model parameters are estimated for the period of 250 trading days ending on day -265 relative to the date of the mistake using a value-weighted CRSP index. Annual restatements are restatements that include a revision of at least 1 annual (audited) report. Quarterly restatements are defined as restatements of quarterly financial statements only and no restatement of an annual (audited) report. Downward (upward) restatements are defined as restatements that result in downward (upward) revision of net income. The numbers in regular font on the horizontal axis show days relative to the mistake. The numbers in italics show days relative to the restatement announcement. MISTAKE marks the beginning of the year of the 1st mistake. RESTATEMENT marks the day of the restatement announcement. We identify all specific dates relative to key events, where $D_{n}^{e}$ is day $n$ relative to event e. A negative value of $n$ indicates days before the event, while a positive $n$ indicates days after the event. For example, the superscript MISTAKE indicates that the date is specified relative to the day of the mistake, with the day of the mistake being day 0 . Superscript RESTATEMENT indicates that days are numbered relative to the day of the restatement, with the day

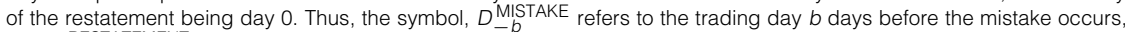
and $D_{a}^{\text {RESTATEMENT }}$ indicates the trading day that falls a days after the restatement announcement. $H$ is the midpoint of the minimum error period. Given these definitions, we plot CARs for 3 periods:

1) the pre-error period $\left(D_{-250}^{\text {MISTAKE }}, D_{0}^{\text {MISTAKE }}\right)$,

2) the error period, including 3 subperiods:

a) early error period ( $D_{1}^{\text {MISTAKE }}, D_{H}^{\text {MISTAKE }}$ ),

b) midpoint $\left[D_{H+1}^{\text {MISTAKE }}, D_{-H-1}^{\text {RESTATEMENT }}\right]$,

c) late error period ( $\left.D_{-H}^{\text {RESTATEMENT }}, D_{-1}^{\text {RESTATEMENT }}\right)$, and

3) the post-restatement period ( $D_{0}^{\text {RESTATEMENT }}, D_{+250}^{\text {RESTATEMENT }}$ ).

For the subsample of downward annual restatements, the minimum error period covers 267 trading days, and hence $H=133, D_{H}^{\text {MISTAKE }}=133, D_{H+1}^{\text {MISTAKE }}=134$, and $D_{-H-1}^{\text {RESTATEMENT }}=-134$. The CARs are calculated around mistakes for the period $(-250,133)$ and around restatements for the period $(-133,250)$. Abnormal returns in the period $\left(D_{134}^{\text {MISTAKE }}, D_{-134}^{\text {RESTATEMENT }}\right)$ are averaged into a 1-day return and are plotted as a single day's abnormal return. For a firm with the minimum error period of 267 days, this is a 1-day window. For other firms, this period varies in length. As a result, the graph shows the minimum error period of length 267 for all firms, even though the error period is firm-specific. Control firms are matched by size and book-to-market within the same 3-digit NAICS code. We compute size as the market value of equity: price per share times the number of shares outstanding. Book-to-market ratio is calculated as the ratio of book value in period $m-1$ divided by the market value of common equity in period $m-1$. Here, $m$ is the year of the firm's mistake (if the firm is restating several years, we calculate the ratio for the year before the 1st restating year). For example, if the company restates 1996 financial statements, we find the matching firm according to the size and book-to-market ratios as of 1995. We eliminate all restating firms from the pool of potential control firms. We also require a control firm to have CRSP returns for as many days as its restating firm 1 year prior to the mistake and 1 year subsequent to the restatement.

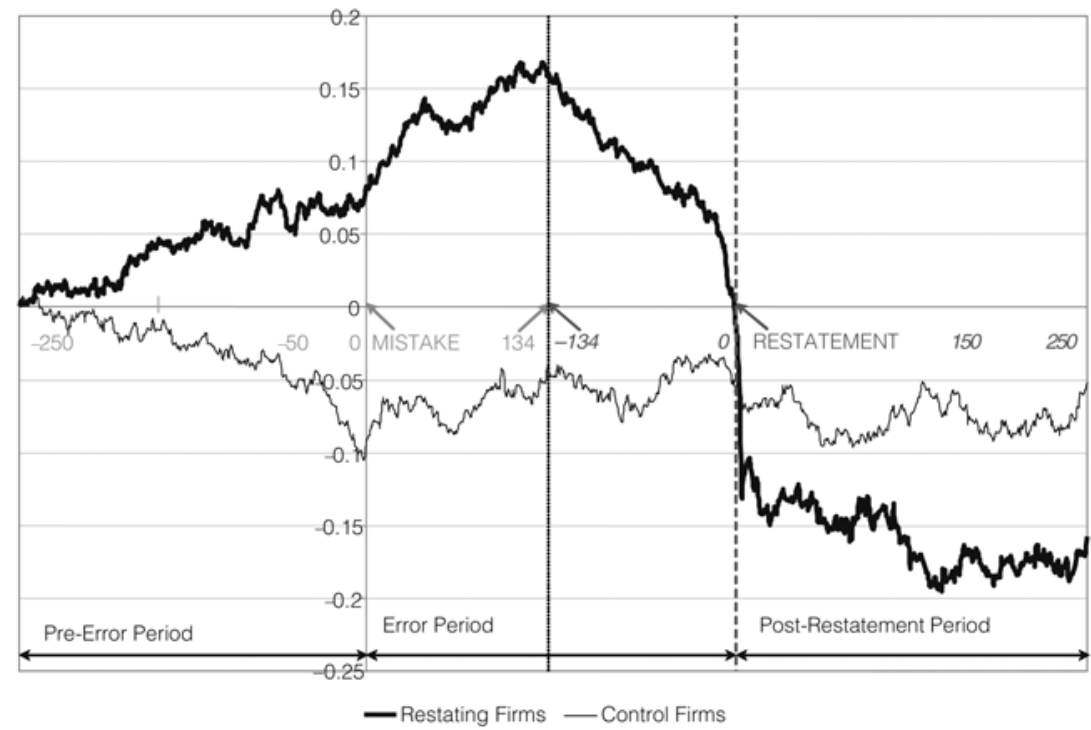




$$
\mathrm{BHR}_{i, \tau}=\prod_{t}^{T}\left(1+R_{i t}\right),
$$

where $R_{i t}$ is the $i$ th firm return on the $t$ th day, and $T$ is the number of trading days in period $\tau$. Here, $\mathrm{BHR}_{i, \tau}$ represents the actual experience of an investor who passively holds a sample firm for the period $\tau$.

Then $\mathrm{BHAR}_{i, \tau}$ is calculated as

$$
\mathrm{BHAR}_{i, \tau}=\mathrm{BHR}_{i, \tau}-\mathrm{E}\left(\mathrm{BHR}_{i, \tau}\right),
$$

where $\mathrm{E}\left(\mathrm{BHR}_{i, \tau}\right)$ is the $\tau$ period expected return for security $i$, proxied by the return on a size and book-to-market matched peer firm in the same industry (3-digit NAICS code) as the restating firm. ${ }^{27}$

First, to allow for direct comparison of results using CARs and BHARs, we show graphs of monthly BHARs for the following periods: i) 1 year before the mistake, ii) the minimum error period (which varies across samples), and iii) 1 year after restatement (Figure 3 ). We assume that the announcement effect covers days $(-1,+5)$ relative to restatement, so that pre-restatement BHARs end on day -2 , and post-restatement BHARs start on day +6 . Each month is assumed to have 21 trading days. Only survivors are included in the calculation of each month's BHARs. Solid bars show BHARs that are significant at $10 \%$ or better, and hollow bars show insignificant BHARs. We test whether BHARs differ statistically from 0 using a $t$-test. Barber and Lyon (1997) and Lyon et al. (1999) show that the control firm approach used in this study eliminates new listing, rebalancing, and skewness biases, and yields well-specified $t$-tests.

Graph A of Figure 3 shows BHARs for annual downward restatements (same sample as that shown in Figure 2). It shows that these restating firms do not experience any abnormal performance prior to a mistake, other than during 1 month immediately preceding the start of the error period, during which they have a positive BHAR of $2.8 \%$ ( $p$-value $=9 \%)$. BHARs during the 1 st part of the error period vary in sign and are not significantly different from 0 , but become negative in the 2 nd part of the error period and are negative and significant at $1 \%$ or better in the last 3 months before restatement announcement. The magnitude of the negative returns prior to restatement is large: BHARs equal $-6.2 \%,-5.3 \%,-5.1 \%$ during months $-3,-2$, and -1 before restatement, respectively. This result suggests that investors anticipate annual downward restatements.

BHAR for the period starting 3 months before the announcement of restatement and ending on day +5 after restatement announcement equals $-28.0 \%$ ( $-29.1 \%$ for survivors only), which is almost 3 times the average 3 -day restatement announcement return. Examination of returns post restatement reveals that restating firms exhibit particularly negative performance in months 5 and 6 after restatement. BHARs for months +5 and +6 equal $-4.61 \%$ and $-4.53 \%$ ( $p$-values of $2 \%$ and $4 \%$ ), respectively.

Graph B of Figure 3 examines BHARs for annual downward restatements of 2 years or more. For these firms we are able to show a longer error period.

\footnotetext{
${ }^{27}$ The 3-digit NAICS code is comparable to the 2-digit Standard Industrial Classification (SIC) code (Bhojraj, Lee, and Oler (2003)).
} 
Overall results are similar for this subset of firms and the full sample of annual downward restatements, especially in pre-error and post-restatement periods. We also observe negative returns before restatement. BHARs are negative and significant only during the month before restatement, and they stay negative and significant 1 month after the restatement. The BHAR in month -1 equals $-7.9 \%$ $(p$-value $=1 \%)$, while the BHAR in month +1 equals $-6.9 \%(p$-value $=6 \%)$. For this sample where the erroneous financial reports persist for more than 2 annual reports, investors appear to start anticipating downward restatements somewhat later, and they take longer to fully impound the information contained in restatement announcements. This result suggests that mistakes that persist for more than 2 years are different and perhaps more difficult for investors to digest.

Graphs C and D of Figure 3 show results for quarterly downward restatements and quarterly downward restatements of 2 quarters or more, respectively.

\section{FIGURE 3}

\section{Monthly BHARs}

Graphs A-E of Figure 3 plot monthly buy-and-hold abnormal returns (BHARs) for 220 annual downward restatements, 104 annual downward restatements of 2 years or more, 143 quarterly downward restatements, 79 quarterly downward restatements of 2 quarters or more, and 35 annual upward restatements announced between January 1, 1997 and June 30, 2002 and control firms, respectively. Annual restatements are restatements that include a revision of at least 1 annual (audited) report. Quarterly restatements are defined as restatements of quarterly financial statements only and no restatement of an annual (audited) report. Downward (upward) restatements are defined as restatements that result in downward (upward) revision of net income. Solid bars show BHARs that are significant at $10 \%$ or better, and hollow bars show insignificant BHARs. We test whether BHARs differ statistically from 0 using a t-test. The numbers in regular font on the horizontal axis show days relative to the mistake. The numbers in italics show days relative to the restatement announcement. MISTAKE marks the beginning of the year of the 1st mistake. RESTATEMENT marks the day of the restatement announcement. Only survivors are included in the calculation of each month's BHARs. Calculations before restatement start on day -2 , and calculations after restatement start on day +6 . Each month is assumed to have 21 trading days. Control firms are matched by size and book-to-market within the same 3-digit NAICS code. We compute size as the market value of equity: price per share times the number of shares outstanding. Book-to-market ratio is calculated as the ratio of book value in period $m-1$ divided by the market value of common equity in period $m-1$. Here, $m$ is the year of the firm's mistake. We eliminate all restating firms from the pool of potential control firms. We also require a control firm to have CRSP returns for as many days as its restating firm 1 year prior to the mistake and 1 year subsequent to the restatement.

Graph A. Monthly BHARs for Annual Downward Restatements

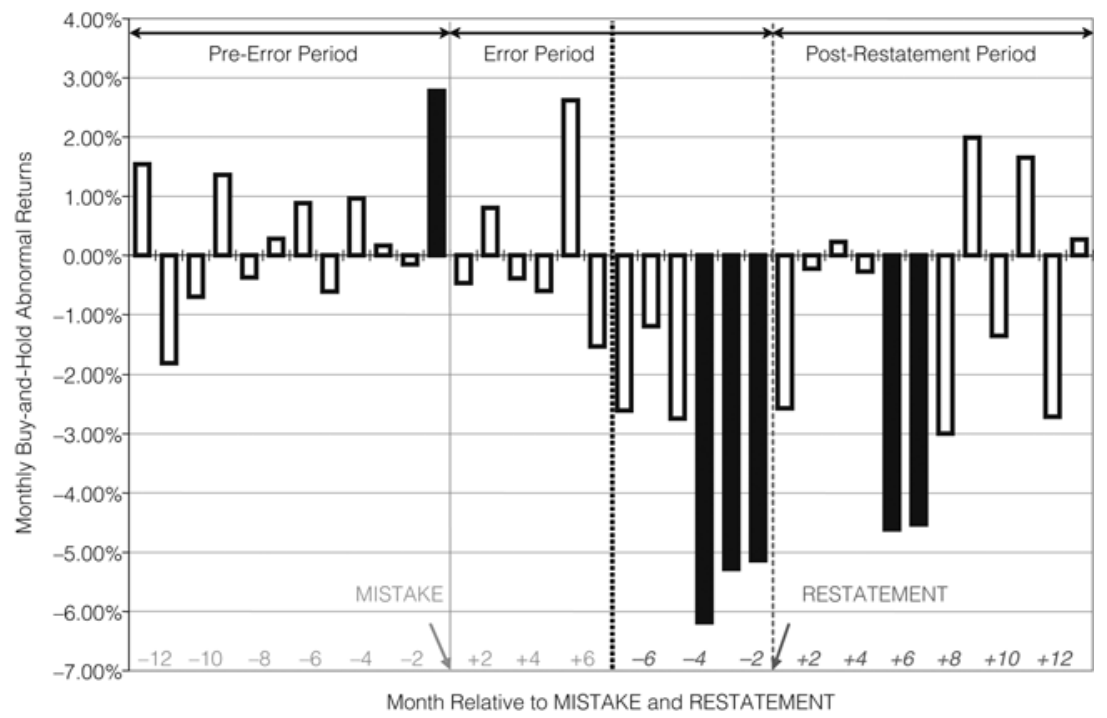


When a firm is restating only 1 quarter, the error period is very short, and there is little time for the market to revise its expectations about the accuracy of the firm's financial data based on comparisons with other firms. Therefore, we focus most of our discussion on the results for restatements of 2 quarters or more (Graph D of Figure 3).

FIGURE 3 (continued)

Monthly BHARs

Graph B. Monthly BHARs for Annual Downward Restatements of 2 Years or More

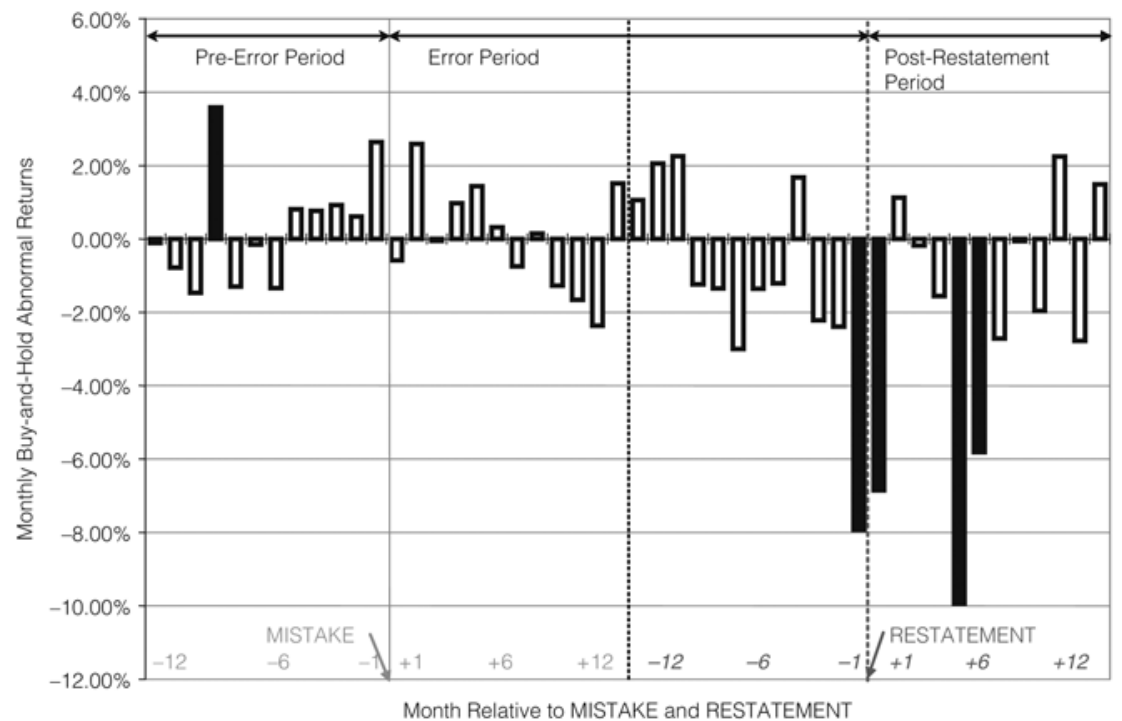

Graph C. Monthly BHARs for Quarterly Downward Restatements

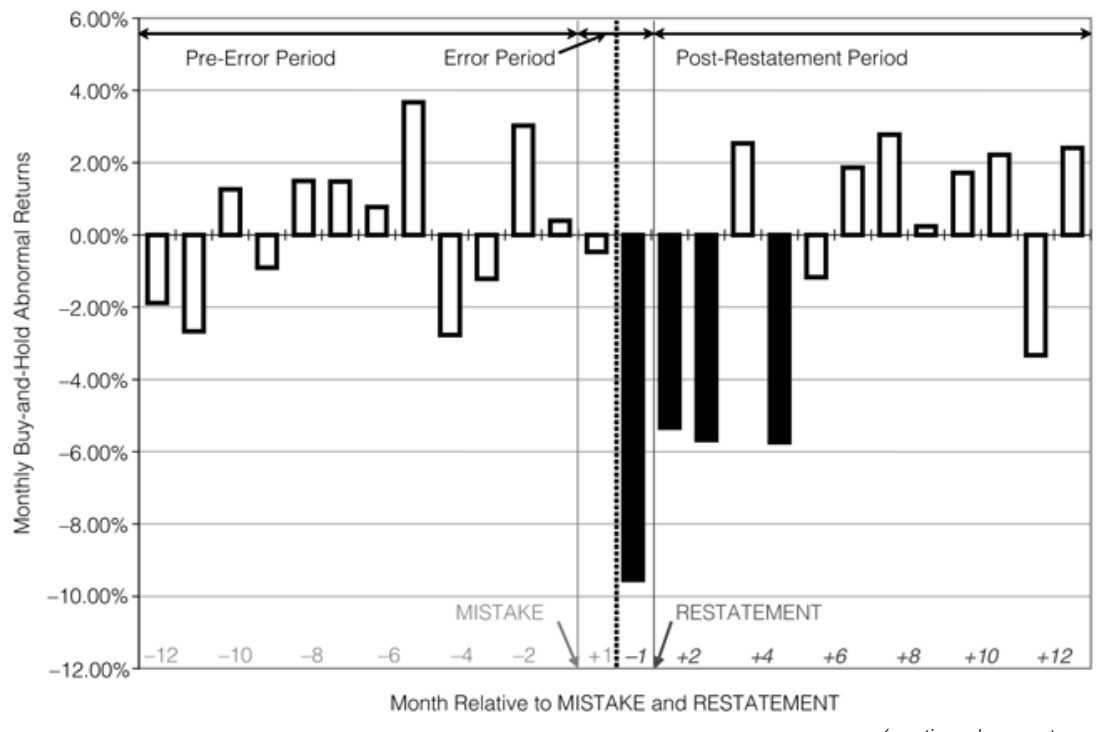


FIGURE 3 (continued)

Monthly BHARs

Graph D. Monthly BHARs for Quarterly Downward Restatements of 2 Quarters or More

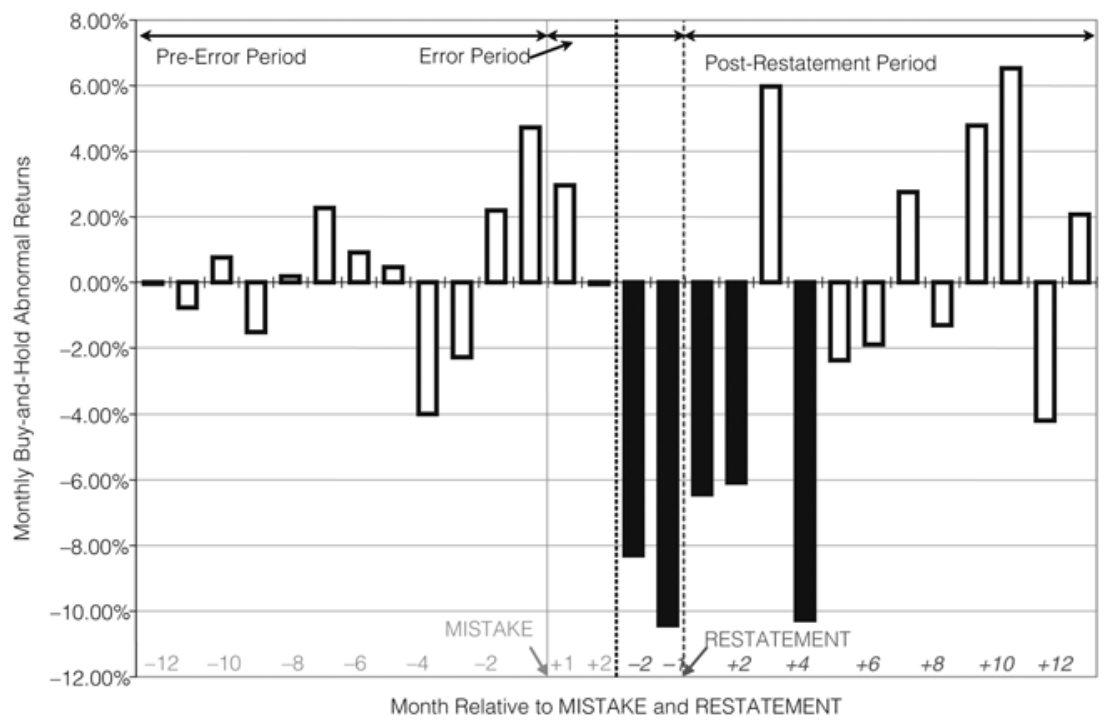

Graph E. Monthly BHARs for Annual Upward Restatements

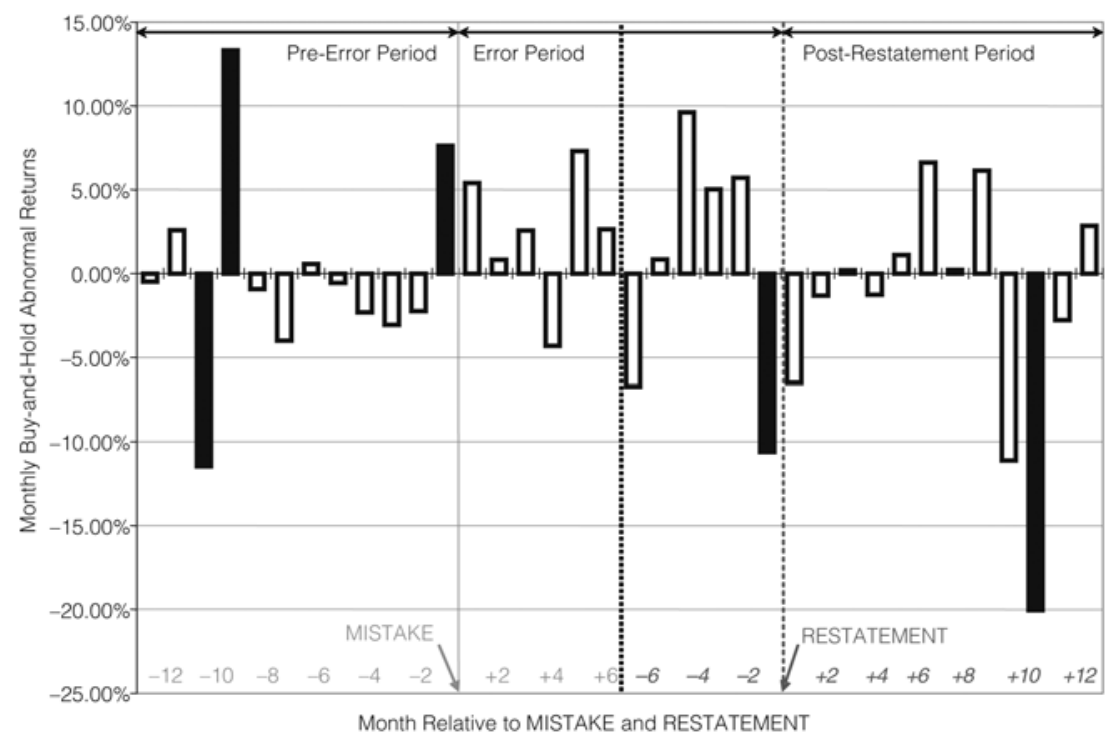

For both samples, we find no abnormal returns prior to mistake and during the 1 st part of the error period. BHARs are negative and significant 1 month before restatement in Graph C of Figure 3 and 2 months before restatement in Graph D, and are negative and significant 2 months after restatement in both figures. In Graph D, BHARs in months -2 and -1 relative to restatement equal $-8.3 \%$ and $-10.4 \%$ with $p$-values of $2 \%$ and $1 \%$, respectively. For this sample, BHARs in 
months -3 and -5 relative to restatement are also significant and equal $-9.8 \%$ in each of those months with $p$-values of $1 \%$ and $4 \%$, respectively. ${ }^{28}$ We also find negative returns in month +4 after restatements in both figures. This result suggests early anticipation of quarterly downward restatements and slow reaction to their announcement. Overall, firms that make quarterly downward restatements lose $33.5 \%$ over 4 months (months $-2,-1,+1$, and +2 ) surrounding the restatement, which is more than 3 times the average restatement announcement affect documented in earlier studies. ${ }^{29}$

Lastly, Graph E of Figure 3 shows monthly BHARs for annual upward restatements. We observe both positive and negative BHARs in the pre-error period: a negative BHAR equal to $-11.5 \%$ in month $-10(p$-value $=1 \%)$, a positive BHAR equal to $13.3 \%$ in month $-9(p$-value $=1 \%)$, and a positive BHAR equal to $7.6 \%$ in month $-1(p$-value $=4 \%)$. These firms also experience negative BHARs of $-10.6 \%(p$-value $=4 \%) 1$ month prior to restatement announcement. Month +10 relative to restatement has a $-11.1 \%$ BHAR $(p$-value $=10 \%)$. We do not place much weight on these results, because there are only 35 upward restatements. Moreover, as shown in the analysis that follows (Table 8), long-run BHARs are insignificant for full pre-error, error, and post-restatement periods for annual upward restatements. Nevertheless, combined with the forthcoming results from Table 8, we can say that upward restatements are not good news, perhaps because they reveal management and internal control system failures.

Table 8 presents further analysis of BHARs in the pre-error, error, and postrestatement periods. The difference between results shown in Figure 3 and Table 8 is that Table 8 splits the error period into quartiles and estimates daily BHARs for each quartile. The length of a quartile is firm-specific, and is calculated by dividing a firm's error period trading days by 4 . We also examine the patterns of BHARs 3 years before mistake and 3 years after restatement, as well as around the announcement of the restatement for windows $(-1,+1)$ and $(-1,+5)$. BHARs in the last quartile of the error period are calculated for the period ending 1 day before the restatement announcement. BHARs in the post-restatement period are calculated starting 5 days after the restatement announcement. We assume that there are 250 trading days in 1 year.

Daily BHARs are found as follows:

(6) $\operatorname{BHAR}_{l}^{\text {PERIOD }}=\sum_{i=1}^{N}\left(\left(\operatorname{BHAR}_{\text {RESTATING }, i, l}^{\text {PERIOD }}-\operatorname{BHAR}_{\text {CONTROL }, i, l}^{\text {PERIOD }}\right) / L_{i}\right) / N$,

where $\mathrm{BHAR}_{l}^{\mathrm{PERIOD}}$ is the daily BHAR for 1 of the 3 periods (pre-error, error, or post-restatement) of length $l$, BHAR $\mathrm{RESTATING}, i, l_{\text {PERIOD }}\left(\mathrm{BHAR}_{\mathrm{CONTROL}, i, l}^{\text {PERIOD }}\right)$ is the buyand-hold return for restating (control) firm $i$ for period $l, L_{i}$ is the number of trading days in the period for firm $i$, and $N$ is the number of firms. To avoid survivorship

\footnotetext{
${ }^{28}$ This result is not shown. Recall that Graph D in Figure 3 shows the error period of the minimum length, and BHARs for each month are calculated for survivors for their respective month only. Therefore, all months shown in figures are nonoverlapping. However, month -3 relative to restatement will overlap with month +2 relative to mistake for firms with the minimum error period.

${ }^{29}$ The BHAR for this window for survivors only equals $30.1 \%$.
} 


\section{TABLE 8}

\section{Buy-and-Hold Abnormal Returns in Pre-Error, Error, and Post-Restatement Periods}

Daily buy-and-hold abnormal returns (BHARs) are computed as the difference between buy-and-hold returns of restating firms and control firms in the same 3-digit NAICS code matched by size and book-to-market in the year before the $1 \mathrm{st}$ mistake. We split the error period into quartiles and estimate daily BHARs for each quartile. Each quartile represents 1 quarter of the entire error period for the specified restating firm. Thus, the length of a quartile is firm-specific and is calculated by dividing the number of trading days in the error period by 4 . We also examine the patterns of BHAR 3 years before mistake and 3 years after restatement, as well as around the restatement announcement windows $(-1,+1)$ and $(-1,+5)$. BHARs in the last quartile of the error period are calculated for the period ending 1 day before restatement announcement. BHARs in the post-restatement period are calculated starting 5 days after the restatement announcement. We assume that there are 250 trading days in 1 year. Daily BHARs are found as follows:

$$
\text { BHAR }_{l}^{\text {PERIOD }}=\sum_{i=1}^{N}\left(\left(\text { BHAR }_{\text {RESTATING }, i, l}^{\text {PERIOD }}, \text { BHAR }_{\text {CONTROL }, i, l}^{\text {PEIOD }}\right) / L_{i}\right) / N
$$

where BHAR PERIOD is the daily BHAR for 1 of the 3 periods (pre-error, error, or post-restatement) of length I, BHAR PERIOD $I, L_{i}$ is the number of trading days in the period for firm $i$, and $N$ is the number of firms. Annual restatements are defined as restatements that include a revision of at least 1 annual report. Quarterly restatements are defined as restatements of less than 4 quarters and no restatement of an annual report. Downward (upward) restatements are defined as restatements that result in downward (upward) revision of net income. Core is a dummy variable that equals 1 if revenue or expense accounts were restated. Fraud is a dummy variable that equals 1 if the company announced fraud as a reason for restatement. The significance of BHARs is tested with $t$-tests. The significance of BHAR differences between subsamples are tested with Wilcoxon nonparametric tests. ${ }^{*},{ }^{* *}$, and ${ }^{* * *}$ indicate significance at the $10 \%, 5 \%$, and $1 \%$ levels, respectively.

$$
\text { Year Relative to Mistake }
$$

$$
\text { Restatement Announcement }
$$
Year Relative to Restatement

Panel A. Daily Buy-and-Hold Abnormal Returns for Annual Downward Restatements

$\begin{array}{ccccccc}\text { Mean } & -0.004 \% & 0.022 \% & 0.002 \% & 0.031 \% & 0.018 \% & -0.053 \% \\ N & 218 & 217 & 217 & 218 & 219 & 219\end{array}$

$0.91 \quad 0.51$

0.51

0.53

219
0.12

Abnormal Returns for Quarterly Downward Restatements

$\begin{array}{lllllll}\text { Mean } & 0.045 \% & 0.055 \% & 0.044 \% & -0.096 \% & -0.300 \% & -0.261 \%\end{array}$

$\begin{array}{lcccccc}N & 143 & 143 & 143 & 142 & 142 & 142 \\ p \text {-value } & 0.39 & 0.29 & 0.39 & 0.19 & <0.01^{\star \star \star} & <0.01^{\star \star *}\end{array}$

Panel C. Daily Buy-and-Hold Abnormal Returns for Annual Upward Restatements

$\begin{array}{lllllll}\text { Mean } & -0.045 \% & -0.029 \% & -0.025 \% & 0.118 \% & 0.053 \% & -0.126 \%\end{array}$

$N$

$-0.045 \%$
35
0.44

$-0.029 \%$
35

35
0.71

35
0.13

35
0.54

35

35
0.65

$4 \quad$ Error Period Daily $(-1,+1) \underline{(-1,+1)}$

Daily $(-1,+5)$

$\underline{(-1,+5)}$

$\begin{array}{ll}1 & 2 \\ \end{array}$

$-0.237 \%-0.079 \%$

$220 \quad 220$

$<0.01^{\text {*** }}$

$-3.943 \%$

$-11.192 \%$

$-1.900 \%$

$-10.386 \%-0.328 \%-0.317 \%-0.307 \%$

$<0.014$ *** $\quad<0.014$

214
$<0.01^{\star \star *}$

$<0.01^{\star \star \star}$

204

$204 \quad 204$

$-0.539 \%-0.308 \%$

$\begin{array}{cc}142 & 142 \\ <0.01^{\text {*** }}<0.01^{\text {** }}\end{array}$

$-3.326 \%$

143

$-9.839 \%$

$-1.416 \%$

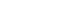

(20.0.

$<0.01^{\star * *}$

143
$<0.01^{\star \star \star}$

$-9.387 \%$
143

143
$0.01^{\star * \star}$

$0.262 \%$
141

$-0.204 \%-0.204 \%$

$<0.01^{\star \star \star}$

$0.015 \%$

$0.425 \%$

$-2.620 \%$

$-7.860 \%$

$-1.068 \%$

35
$0.03^{\star *}$

$-7.478$

35
$0.03^{* *}$

$0.03^{\star \star}$

\begin{tabular}{ccc}
35 & 35 & 35 \\
0.20 & 1.00 & 0.73 \\
\multicolumn{3}{r}{} \\
\multicolumn{3}{r}{ (continued on next page) }
\end{tabular} 


\section{TABLE 8 (continued)}

Buy-and-Hold Abnormal Returns in Pre-Error, Error, and Post-Restatement Periods

$\underline{\text { Panel D. Core vs. Noncore - Annual Downward Restatements }}$

\begin{tabular}{|c|c|c|c|c|c|c|c|c|}
\hline & \multicolumn{4}{|c|}{$\begin{array}{c}\text { Core } \\
\text { Quartiles of the Error Period }\end{array}$} & \multicolumn{4}{|c|}{$\begin{array}{l}\text { Noncore } \\
\text { Quartiles of the Error Period }\end{array}$} \\
\hline & 1 & 2 & 3 & 4 & 1 & 2 & 3 & 4 \\
\hline $\begin{array}{l}\text { Mean } \\
N \\
p \text {-value }\end{array}$ & $\begin{array}{c}0.08 \% \\
103 \\
0.24\end{array}$ & $\begin{array}{c}-0.01 \% \\
104 \\
0.90\end{array}$ & $\begin{array}{c}-0.07 \% \\
104 \\
0.21\end{array}$ & $\begin{array}{c}-0.34 \% \\
105 \\
<0.01^{\star \star *}\end{array}$ & $\begin{array}{c}-0.02 \% \\
115 \\
0.74\end{array}$ & $\begin{array}{c}0.04 \% \\
115 \\
0.31\end{array}$ & $\begin{array}{c}-0.04 \% \\
115 \\
0.37\end{array}$ & $\begin{array}{c}-0.14 \% \\
115 \\
0.01^{\star \star \star}\end{array}$ \\
\hline $\begin{array}{l}\text { Difference between Core and Noncore } \\
\text { Wilcoxon } \operatorname{Pr}>Z\end{array}$ & $\begin{array}{l}0.10 \% \\
0.59\end{array}$ & $\begin{array}{l}-0.04 \% \\
0.14\end{array}$ & $\begin{array}{l}-0.03 \% \\
0.85\end{array}$ & $\begin{array}{r}-0.20 \% \\
0.05^{\star *}\end{array}$ & & & & \\
\hline \multicolumn{9}{|c|}{ Panel E. Core vs. Noncore - Quarterly Downward Restatements } \\
\hline & \multicolumn{4}{|c|}{$\begin{array}{c}\text { Core } \\
\text { Quartiles of the Error Period }\end{array}$} & \multicolumn{4}{|c|}{$\begin{array}{l}\text { Noncore } \\
\text { Quartiles of the Error Period }\end{array}$} \\
\hline & 1 & 2 & 3 & 4 & 1 & 2 & 3 & 4 \\
\hline $\begin{array}{l}\text { Mean } \\
N \\
p \text {-value }\end{array}$ & $\begin{array}{c}-0.02 \% \\
77 \\
0.88\end{array}$ & $\begin{array}{c}-0.31 \% \\
77 \\
0.02^{\star \star}\end{array}$ & $\begin{array}{c}-0.31 \% \\
77 \\
0.01^{\star \star \star}\end{array}$ & $\begin{array}{c}-0.77 \% \\
77^{*} \\
<0.01^{\star * *}\end{array}$ & $\begin{array}{c}-0.19 \% \\
65 \\
0.03^{\star \star}\end{array}$ & $\begin{array}{c}-0.29 \% \\
65 \\
0.02^{\star \star}\end{array}$ & $\begin{array}{c}-0.20 \% \\
65 \\
0.04^{\star \star}\end{array}$ & $\begin{array}{c}-0.27 \% \\
65 \\
0.01^{\star \star \star}\end{array}$ \\
\hline $\begin{array}{l}\text { Difference between Core and Noncore } \\
\text { Wilcoxon } \operatorname{Pr}>Z\end{array}$ & $\begin{array}{l}0.17 \% \\
0.12\end{array}$ & $\begin{array}{l}-0.01 \% \\
0.76\end{array}$ & $\begin{array}{l}-0.10 \% \\
0.78\end{array}$ & $\begin{array}{r}-0.51 \% \\
0.01^{\star \star \star}\end{array}$ & & & & \\
\hline \multicolumn{9}{|c|}{ Panel F. Fraud vs. Nonfraud - Annual Downward Restatements } \\
\hline & \multicolumn{4}{|c|}{$\begin{array}{l}\text { Fraud } \\
\text { Quartiles of the Error Period }\end{array}$} & \multicolumn{4}{|c|}{$\begin{array}{c}\text { Nonfraud } \\
\text { Quartiles of the Error Period }\end{array}$} \\
\hline & 1 & 2 & 3 & 4 & 1 & 2 & 3 & 4 \\
\hline $\begin{array}{l}\text { Mean } \\
N \\
p \text {-value }\end{array}$ & $\begin{array}{c}0.15 \% \\
43 \\
0.23\end{array}$ & $\begin{array}{c}0.07 \% \\
43 \\
0.45\end{array}$ & $\begin{array}{c}-0.12 \% \\
43 \\
0.04^{\star \star}\end{array}$ & $\begin{array}{c}-0.12 \% \\
43 \\
0.01^{\star * *}\end{array}$ & $\begin{array}{c}0.00 \% \\
175 \\
1.00\end{array}$ & $\begin{array}{c}0.01 \% \\
176 \\
0.82\end{array}$ & $\begin{array}{c}-0.04 \% \\
176 \\
0.35\end{array}$ & $\begin{array}{c}-0.27 \% \\
177 \\
<0.01^{\star \star \star}\end{array}$ \\
\hline $\begin{array}{l}\text { Difference between Fraud and Nonfraud } \\
\text { Wilcoxon } \operatorname{Pr}>Z\end{array}$ & $\begin{array}{l}0.15 \% \\
0.10^{\star}\end{array}$ & $\begin{array}{l}0.06 \% \\
0.63\end{array}$ & $\begin{array}{l}-0.08 \% \\
0.22\end{array}$ & $\begin{array}{l}0.14 \% \\
0.67\end{array}$ & & & & \\
\hline
\end{tabular}

bias, we report results for a sample with firms that have any returns in the period studied, rather than a sample that had returns for the entire period (survivors).

Panel A of Table 8 shows that firms making annual downward restatements have 0 BHARs before their mistakes. BHARs in the error period are positive but insignificant in the 1 st and 2nd quartiles, but become negative in the 3rd quartile, and negative and significant in the 4th quartile. BHARs decrease from quartile to quartile as the restatement announcement approaches. Overall results are consistent with investors being initially fooled by erroneous financial reports but nevertheless anticipating restatements.

Confirming results of prior studies, we find negative and significant returns at the announcement of the restatement. The BHAR for the window $(-1,+1)$ is $-11.19 \%$. We also find that restating firms underperform up to 3 years after a restatement. However, this result does not hold for any of the post-restatement periods when we examine only survivors, suggesting that poorer performers stop trading. ${ }^{30}$ All other results in this panel are robust when the sample is limited to survivors only.

\footnotetext{
${ }^{30}$ When we analyze survivors only, the sample drops to 133,110 , and 92 observations for years +1 , +2 , and +3 relative to restatement, respectively.
} 
The BHAR results for quarterly downward restatements are similar to those of annual downward restatements (Panel B of Table 8). However, quarterly downward restating firms start experiencing negative performance in the error period much sooner, in the 2nd quartile of the error period. When we analyze survivors only, positive BHARs 2 years before restatement and negative BHARs 3 years after restatement become significant. The rest of the results are unchanged.

Panel $\mathrm{C}$ of Table 8 shows that firms making annual upward restatements do not exhibit statistically significant abnormal performance in any of the periods, except for a $-7.86 \%$ announcement effect. ${ }^{31}$ If investors had mistakenly used understated earnings to project future earnings, one might expect a positive announcement effect. Negative reaction to the restatement of net income upward suggests that restatements, up or down, increase expected costs to all restating firms in terms of reputation, operating expenses, and expected legal expenses. ${ }^{32}$ Overall, the analysis in Figures 2 and 3 and Table 8 suggests that investors anticipate downward restatements.

\section{Further Analysis: Core and Fraud Restatements}

We also examine whether investors rely more on core accounts. Previous literature found that markets react more strongly to surprises in ongoing operating income than to one-time special items (Elliott and Hanna (1996)). If this is true and investors are misled, misstatement of core accounts (revenue and expense accounts) should result in greater misvaluation and abnormal returns. Alternatively, investors may pay closer attention to core accounts and start seeing mistakes in such accounts sooner. Arguably, intentional fraudulent misstatements of financial results are more difficult for investors to see through than random mistakes and make it more difficult for investors to estimate true earnings. Hence, restatements due to fraud could cause greater misvaluation. ${ }^{33}$ We rely on the firm's restatement announcement to identify cases where fraud was involved.

Specifically, we test whether valuation in the error period is different for restatements of core versus noncore accounts and fraudulent restatements for annual and quarterly downward restatements. Due to small sample size, we do not perform this analysis for annual upward restatements. ${ }^{34}$

\footnotetext{
${ }^{31}$ Results are not affected by restricting the sample to survivors only.

${ }^{32}$ To check the robustness of the results, we calculated BHARs for fixed-length windows relative to mistake and restatement. Specifically, we calculated BHARs for 3, 6, 9, 12, 15, 18, and 24 months relative to mistake and restatement for annual restatements, and for 3, 6, 9, and 12 months for quarterly restatements. The results are consistent with those found using firm-specific quartiles of the error period (Table 7) and using monthly BHARs (Figure 3), so we do not report them here.

${ }^{33}$ Prior studies find that the pressure to sustain positive earnings growth, inflation of CEO compensation, and issuance of equity and debt at favorable prices can motivate managers to intentionally misreport (Richardson et al. (2003), Efendi et al. (2007), and Burns and Kedia (2007)). Offsetting these motivations is the fact that restatement of financial reports is a negative event for the management of the firm: Management loses credibility with shareholders, customers, and employees and is often forced to resign (Desai, Hogan, and Wilkins (2006)).

${ }^{34}$ We also reestimated equation (2) and interact MISTAKE with CORE and FRAUD dummy variables, where CORE equals 1 if revenue or expense accounts were restated and FRAUD equals 1 if the company announced fraud as a reason for restatement (the results are not shown). The coefficient
} 
Panel D of Table 8 presents error period BHARs for subsamples of restatements of core and noncore accounts for annual downward restatements. We find that the 4th quartile BHARs are much lower for the core subsample. ${ }^{35}$ This result could be due to the fact that investors pay more attention to core accounts and penalize firms misstating core accounts more, or start to notice those mistakes sooner. Panel E of Table 8 compares error period BHARs for the sample of quarterly downward restatements and finds similar evidence. Panel F of Table 8 examines error period BHARs for fraud and nonfraud subsamples and shows that 1 st quartile BHARs are positive for the fraud subsample and are significantly higher than those for the nonfraud subsample. It appears that fraudulent mistakes mislead the market more in the 1 st quartile of the error period. We do not analyze fraud and nonfraud subsamples for quarterly downward restatements because they contain only 6 fraudulent restatements.

\section{Conclusion}

This paper tests whether investors see through mistakes in reported earnings by examining market reaction to initially reported erroneous earnings and valuation of restating firms during the error period, before earnings are corrected. We also examine the long-run return performance of restating companies in 3 periods: i) the period prior to the mistake (pre-error period); ii) the period after the mistake has been made but before the restatement (error period); and iii) the period after the restatement (post-restatement period). We focus on the error period, which we split into 4 quartiles.

Results show that investors are initially misled by mistakes in financial statements. At the initial announcement of erroneous earnings, investors treat the error component of earnings the same as the true component. However, valuation of the error component decreases as the restatement date approaches, suggesting that investors start to catch on sometime before a restatement occurs. Valuation (CAR and BHAR) trends measured during the error period also show that investors anticipate restatements. We find that restating firms that overstate net income underperform the market and matched control firms several months before their restatement announcements.

Overall, our evidence suggests that investors are initially misled by misstated earnings but start seeing through mistakes as the restatement date approaches. When anticipation of a restatement is taken into account, the effect of the restatement is more than 3 times its announcement effect. Our results support the view that better quality of financial information could benefit investors.

\section{References}

Agrawal, A., and S. Chadha. "Corporate Governance and Accounting Scandals." Journal of Law and Economics, 48 (2005), 371-406.

Agrawal, A., and T. Cooper. "Insider Trading Before Accounting Scandals." Working Paper, University of Alabama (2007).

estimates for both interactions are not significant, suggesting that at restatement announcement investors do not react differently to mistakes associated with fraud and made in core accounts.

${ }^{35}$ We test for the difference using the nonparametric Wilcoxon test. 
Badertscher, B.; D. W. Collins; and T. Z. Lys. "Earnings Management and the Predictive Ability of Accruals with Respect to Future Cash Flows." Working Paper, University of Notre Dame, University of Iowa, and Northwestern University (2007).

Ball, R., and P. Brown. "An Empirical Evaluation of Accounting Income Numbers." Journal of Accounting Research, 6 (1968), 159-178.

Ball, R., and S. P. Kothari. "Security Returns around Earnings Announcements." Accounting Review, 66 (1991), 718-738.

Barber, B. M., and J. D. Lyon. "Detecting Long-Run Abnormal Stock Returns: The Empirical Power and Specification of Test Statistics." Journal of Financial Economics, 43 (1997), 341-372.

Bardos, K. S.; J. Golec; and J. P. Harding. "Litigation Risk and Market Reaction to Restatements." Working Paper, University of Connecticut and Fairfield University (2011).

Beaver, W. "The Information Content of Annual Earnings Announcements." Empirical Studies in Accounting: Selected Studies, Supplement to Journal of Accounting Research, 10 (1968), 1-38.

Bhojraj, S.; C. M. C. Lee; and D. K. Oler. "What's My Line? A Comparison of Industry Classification Schemes for Capital Market Research.” Journal of Accounting Research, 41 (2003), 745-774.

Block, S. B. "A Study of Financial Analysts: Practice and Theory." Financial Analysts Journal, 55 (1999), 86-95.

Bradshaw, M. T., and R. G. Sloan. "GAAP versus the Street: An Empirical Assessment of Two Alternative Definitions of Earnings.” Journal of Accounting Research, 40 (2002), 41-66.

Burns, N., and S. Kedia. "The Impact of Performance-Based Compensation on Misreporting." Journal of Financial Economics, 79 (2007), 35-67.

Chari, V. V.; R. Jagannathan; and A. R. Ofer. "Seasonalities in Security Returns: The Case of Earnings Announcements.” Journal of Financial Economics, 21 (1988), 101-121.

Chen, X.; Q. Cheng; and A. K. Lo. "The Consequence of Aggressive Financial Reporting: The Case of External Financing." Working Paper, University of Wisconsin-Madison and University of British Columbia (2009).

Cohen, D. A.; A. Dey; T. Z. Lys; and S. V. Sunder. "Earnings Announcement Premia and the Limits to Arbitrage." Journal of Accounting and Economics, 43 (2007), 153-180.

Collins, D. W., and S. P. Kothari. "An Analysis of Intertemporal and Cross-Sectional Determinants of Earnings Response Coefficients.” Journal of Accounting and Economics, 11 (1989), 143-181.

Dechow, P. M., and D. J. Skinner. "Earnings Management: Reconciling the Views of Accounting Academics, Practitioners, and Regulators." Accounting Horizons, 14 (2000), 235-250.

DeFond, M. L., and J. Jiambalvo. "Incidence and Circumstances of Accounting Errors." Accounting Review, 66 (1991), 643-655.

De la Merced, M. J. "Auditor Could Face Liability in Lehman Case." New York Times (March 15, 2010), B.2.

Desai, H.; C. E. Hogan; and M. S. Wilkins. "The Reputational Penalty for Aggressive Accounting: Earnings Restatements and Management Turnover.” Accounting Review, 81 (2006), 83-112.

Desai, H.; S. Krishnamurthy; and K. Venkataraman. "Do Short Sellers Target Firms with Poor Earnings Quality? Evidence from Earnings Restatements.” Review of Accounting Studies, 11 (2006), 71-90.

Efendi, J.; M. Kenney; and E. P. Swanson. "Can Short Sellers Predict Accounting Restatements?" Working Paper, Texas A\&M University (2004).

Efendi, J.; A. Srivastava; and E. P. Swanson. "Why Do Corporate Managers Misstate Financial Statements? The Role of Option Compensation and Other Factors." Journal of Financial Economics, 85 (2007), 667-708.

Elliott, J. A., and J. D. Hanna. "Repeated Accounting Write-Offs and the Informational Content of Earnings." Journal of Accounting Research (Supplement), 34 (1996), 135-155.

Frieder, L., and D. Shanthikumar. "Investor and Price Reaction to Earnings Restatements." Working Paper, Harvard University and Purdue University (2007).

General Accounting Office. "Financial Statement Restatements: Trends, Market Impacts, Regulatory Responses, and Remaining Challenges.” GAO-03-138 (2002).

Graham, J. R.; C. R. Harvey; and S. Rajgopal. "The Economic Consequences of Corporate Financial Reporting." Journal of Accounting and Economics, 40 (2005), 3-73.

Graham, J. R.; S. Li; and J. Qiu. "Corporate Misreporting and Bank Loan Contracting." Journal of Financial Economics, 89 (2008), 44-61.

Griffin, P. A. "A League of Their Own? Financial Analysts' Responses to Restatements and Corrective Disclosures." Journal of Accounting, Auditing, and Finance, 18 (2003), 479-518.

Hribar, P., and N. T. Jenkins. "The Effect of Accounting Restatements on Earnings Revisions and the Estimated Cost of Capital." Review of Accounting Studies, 9 (2004), 337-356.

Hribar, P.; N. T. Jenkins; and J. Wang. "Institutional Investors and Accounting Restatements.” Working Paper, University of Iowa, Vanderbilt University, and Singapore Management University (2005). 
Jensen, M. C. “Agency Costs of Overvalued Equity.” Financial Management, 34 (2005), 5-19.

Kahle, K. M., and R. A. Walkling. "The Impact of Industry Classifications on Financial Research." Journal of Financial and Quantitative Analysis, 31 (1996), 309-335.

Karpoff, J. M.; D. S. Lee; and G. S. Martin. "The Cost to Firms of Cooking the Books.” Journal of Financial and Quantitative Analysis, 43 (2008), 581-612.

Kedia, S., and T. Philippon. "The Economics of Fraudulent Accounting." Review of Financial Studies, 22 (2009), 2169-2199.

Kinney, W. R. Jr., and L. S. McDaniel. "Characteristics of Firms Correcting Previously Reported Quarterly Earnings.” Journal of Accounting and Economics, 11 (1989), 71-93.

Kothari, S. P., and J. B. Warner. "Measuring Long-Horizon Security Price Performance.” Journal of Financial Economics, 43 (1997), 301-339.

Kravet, T., and T. Shevlin. "Accounting Restatements and Information Risk." Review of Accounting Studies, 15 (2010), 264-294.

Landsman, W. R., and E. L. Maydew. "Has the Information Content of Quarterly Earnings Announcements Declined over the Past Three Decades?" Journal of Accounting Research, 40 (2002), 797-808.

Livnat, J., and R. R. Mendenhall. "Comparing the Post-Earnings Announcement Drift for Surprises Calculated from Analyst and Time Series Forecasts." Journal of Accounting Research, 44 (2006), 177-205.

Lyon, J. D.; B. M. Barber; and C.-L. Tsai. "Improved Methods for Tests of Long-Run Abnormal Stock Returns.” Journal of Finance, 54 (1999), 165-201.

Palmrose, Z.-V.; V. J. Richardson; and S. Scholz. "Determinants of Market Reactions to Restatement Announcements." Journal of Accounting and Economics, 37 (2004), 59-89.

Richardson, S.; A. Tuna; and M. Wu. "Predicting Earnings Management: The Case of Earnings Restatements." Working Paper, University of Pennsylvania, and Hong Kong University of Science and Technology (2003).

Spiess, D. K., and J. Affleck-Graves. "The Long-Run Performance of Stock Returns following Debt Offerings." Journal of Financial Economics, 54 (1999), 45-73.

Wilson, W. M. "An Empirical Analysis of the Decline in the Information Content of Earnings following Restatements." Accounting Review, 83 (2008), 519-548. 